\title{
Asturianos en América. Fotografía, identidad y traje tradicional en la emigración (1880-1900)
}

\author{
Asturians in America. Photography, Identity \\ and Traditional Costume in Emigration (1880-1900)
}

\author{
Fe Santoveña Zapatero \\ Investigadora independiente \\ galardeyu@gmail.com
}

\section{RESUMEN}

A mediados del siglo XIX un sector de la sociedad asturiana, relacionada con las élites intelectuales vinculadas al regionalismo romántico, fijaron los estereotipos de una indumentaria que pasará a ser conocida como "traje del país o traje asturiano", con el que se identificarán tanto el folclore y las tradiciones populares, como una idea de unidad territorial e identitaria heredera de un heroico pasado. Los emigrantes en Latinoamérica reformularon la expresión estética de estos atuendos de acuerdo con las costumbres locales, generando un traje híbrido en el que se aunaron las costumbres recordadas de la lejana Asturias y las expresiones culturales de los países de acogida. Así ataviados, los asturianos en la emigración posaron para la fotografía, dejando testimonio gráfico de las nuevas identidades mixtas surgidas en las postrimerías del colonialismo español allende el mar.

Palabras clave: Indumentaria; Tradicional; Emigración; Identidad; Fotografía.

\section{SUMMARY}

In the mid-nineteenth century, a sector of Asturian society related to the intellectual elites that espoused romantic regionalism, established clothing stereotypes of that would become known as regional or Asturian costume. These would later be identified with folklore and popular traditions, conveying a territorial and identity unity inherited from a heroic past. Emigrants to Latin America reformulated the aesthetic expression of these outfits in line with local customs, creating a hybrid costume which combined customs remembered from distant Asturias and the cultural expressions of the host countries. Thus clad, Asturian emigrants posed for the picture, leaving graphic testimony of the new mixed identities that emerged in the aftermath of Spanish colonialism overseas.

Key words: Clothing; Traditional; Emigration; Identity; Photography.

\section{INTRODUCCIÓN}

Hablar y pensar se consideran tareas exclusivamente humanas (Elías 1994), que nos diferencian de cualquier otra especie animal que exista, pero no son las únicas. Actualmente vestirse, cubrir el cuerpo artificialmente con elementos confeccionados particular- 
mente para ello, es también una característica única de nuestra especie. Mediante el lenguaje de las ropas expresamos cuestiones relacionadas con la edad, el género, la profesión a la que nos dedicamos o nuestro estatus social. Los trajes se convierten en un código mediante el cual comunicamos elementos relacionados con nuestra identidad.

Como parte de este lenguaje de identidad e identificación con un territorio, los llamados trajes regionales, trajes del país o indumentarias tradicionales, han servido desde mediados del siglo XIX como elementos simbólicos para representar diferentes espacios geográficos de España, asociados con los ricos pasados históricos, las costumbres tradicionales y el variado folclore de cada una de ellas. Una forma de conservar y difundir esos vestidos fue posando para un retrato fotográfico, siguiendo la costumbre de hacerse una fotografía que se había extendido entre todas las clases sociales, después del abaratamiento de los costos de obtención de una imagen tras la difusión del sistema de positivo negativo que Henry Fox Talbot diera a conocer en 1842.

\section{LA FOTOGRAFÍA COMO FUENTE EN ANTROPOLOGÍA SOCIAL Y CULTURAL}

La documentación aportada por el registro fotográfico ha ido abriéndose camino poco a poco en el ámbito de las ciencias sociales como una más de las muchas fuentes de información con las que cuenta un investigador. Se ha hecho historia de la fotografía en sí misma y se la ha utilizado como materia para ilustrar hechos y acontecimientos del pasado, pero pocas veces se la trató directamente como fuente de información primaria para una investigación. Este sin embargo ha sido el caso para el estudio realizado en estas páginas, en la que la documentación fotográfica es utilizada como base fundamental para la argumentación. No se trata de utilizar las imágenes para ilustrar un texto, sino de que texto e imagen funcionen como elementos conjuntos para establecer una teoría y documentarla fehacientemente. Las imágenes serán la cita y el documento necesario, parte integrada del discurso y no una aportación prescindible que lo acompañe, como explica Emilio Luis Lara López (Lara López 2005: 9).

Si concebir y fijar por escrito un discurso histórico para después ilustrarlo con fotografías es, sin lugar a dudas el proceso claro del historiador, se le puede dar la vuelta a dicho procedimiento y considerar a aquellas no como elementos ilustradores accesorios, divulgativos, ya que las imágenes alegran el texto, sino un elemento documental prioritario, esencial, para a partir de la información suministrada visualmente en función del universo acotado espacio-temporalmente en cada foto, elaborar un discurso histórico, ayudándose del resto de fuentes históricas que no habrán de desdeñarse ni mucho menos.

Tales principios pueden ser extendidos a trabajos realizados en el campo de la antropología social, como explica José Carmelo Lisón Arcal (2005: 15)

[...] poner de manifiesto las grandes posibilidades que nos ha venido ofreciendo la fotografía, tanto para recopilar información como para analizarla y presentar resultados, en contraste con el hecho de que todavía encontramos reticencias a su utilización de forma sistemática y habitual en el campo antropológico.

El manejo de esta documentación requiere, de todos modos, aclarar una serie de cuestiones de método importantes que permitan elaborar partiendo de ella un discurso coherente. Se trataría principalmente de "encuestar" a la imagen, de plantearse un inte- 
rrogatorio y ver a cuantas de las preguntas previstas pueden responder las fotografías. En primer lugar se debe tener un conocimiento básico de la historia de la fotografía en general, de sus tecnologías y sus técnicas, que ayudarán a perfilar una datación lo más fiable posible de los materiales con los que se vaya a trabajar. Los procesos de fijación y positivado de imágenes constituyen una buena forma de aproximación cronológica, especialmente si se trata de aquellas que fueron poco utilizadas, mientras que otras tuvieron un largo recorrido en el tiempo como los positivos a la albúmina sobre papel. Debe tenerse en cuenta que pese a su popularidad, muchos de estos métodos no fueron los únicos utilizados en un mismo periodo cronológico y que algunos continuaron usándose de forma residual tiempo después de su momento de máxima utilización.

Asimismo, el aspecto formal referido al tamaño final de la fotografía, al igual que aspectos variados que forman parte de su estética, como los telones de fondo, las poses estudiadas y las composiciones de grupos, nos hablan de quién y por qué se hacía una fotografía, de las posibilidades económicas de invertir en la misma y del objetivo final con el que se realizaba. Pese a la pretensión de atrapar la realidad en un momento — de donde le viene su nombre de instantánea— nada puede ser más incierto que una calificación de ésta naturaleza. Como sinónimo de fotografía se ha utilizado el término composición que remite a la pintura, y que como en el caso de esta última, explicita claramente que la imagen se ha organizado, arreglado y preparado para obtener un determinado fin: transmitir a quien mira una imagen escogida y premeditada por parte de quien posa o retrata (Sontag 2002: 20).

Cuando deciden la apariencia de una imagen, cuando prefieren una exposición a otra, los fotógrafos siempre imponen pautas a sus modelos. Aunque en un sentido la cámara en efecto captura la realidad, y no solo la interpreta, la fotografía es una interpretación del mundo tanto como las pinturas y los dibujos.

Se trata por tanto de una construcción del "yo", del "nosotros", del fotografiado y del fotógrafo, destinada a ser interpretada de acuerdo con unos códigos simbólicos por un o unos "Otros" que miran y reconocen esos símbolos. El retrato crea, por su misma naturaleza de representar a un individuo o un grupo de individuos unidos por una identidad común que les lleva a ponerse ante la cámara, un espacio de identidades y alteridades: de afinidad o desigualdad en función de la intencionalidad con la que se haya hecho y de cual sea su destino de uso. No es lo mismo un retrato enviado desde la emigración, un recuerdo de matrimonio o un posado con un disfraz festivo. Tampoco es lo mismo una imagen hecha para la exhibición pública en álbumes, una forma en la que las clases acomodadas mostraban su modernidad y su estatus social, o para ser expuesta como un cuadro con unas intenciones semejantes, que una tarjeta de visita o la pequeña efigie dedicada que se envían entre si los enamorados, acompañada de un escrito en el que se manifiestan emociones y sentimientos privados. La fotografía no es un mundo plenamente objetivo, sino cargado de subjetividades, y toda imagen utilizada como fuente documental debe someterse a esta crítica, puesto que de no hacerlo supondría perder una parte importante de la propia acción de fotografiar, según refleja el filósofo Vilem Flusser (Flusser 1990: 11).

La actitud acrítica es peligrosa porque la "objetividad" de la imagen técnica es una ilusión. Las imágenes técnicas son, en verdad, imágenes, y como tales, son simbólicas. De hecho, son un complejo simbólico aún más abstracto que las imágenes tradicionales. 
Las indumentarias populares serán tratadas aquí como elementos simbólicos de una identidad particular, como elementos de identificación con un grupo cultural particularización adscrito a un territorio delimitado, sin que sea necesario que la persona que busca esa identificación viva necesariamente en el lugar. Si partimos de una acción emblemática específica, la de vestirse con un traje regional o un traje de "el país", la de posar para el objetivo de una cámara ataviado con el mismo no es menos singular. Este acto constituye una moda dentro la práctica común de hacerse un retrato, siendo esto último una acción facilitada por la difusión de fotografía (Freund 1983) que termina constituyendo un habitus (Bourdieu 1984), una costumbre establecida y aceptada continuada en el tiempo, y que se ha manifestado de acuerdo a distintos modelos desde los inicios de la instantánea, hace más de ciento setenta y cinco años, hasta el presente, generando una vinculaciones efímeras entre los que se fotografían, quien los fotografía y quien mira esos retratos (Sontag 2002), con la referencia última de cuáles son las razones por las que lo hacen, instituyendo esa misma acción de fotografiarse un estado de liminaridad (Turner 1988), de apartamiento temporal de la sociedad en tanto que dura el tiempo de hacerse el retrato y que perdura en el resultado de la misma como un elemento de la memoria, mucho tiempo después de haberse deprendido de las ropas singulares.

\section{VESTIDOS DE ASTURIANOS}

Por traje asturiano, traje del país o indumentaria tradicional asturiana se conocen las modas con las que se vistieron los campesinos y artesanos del Principado de Asturias desde finales del siglo XVIII hasta mediados del siglo XIX (Fernande 2007). Al igual que ocurre en otras muchas regiones españolas y como parte de un proceso general europeo, su condición de trajes identitarios —asociados con unas costumbres consideradas como tradicionales y representativas de un ethos particular asturiano, así como con unas manifestaciones específicas folclóricas y musicales - fue llevada a cabo por una élite cultural burguesa, heredera de los ideales del sentimiento nacionalista romántico, de reconocimiento de un pasado heroico y de una identificación con unos valores tradicionales idealizados que se oponían, paradójicamente, a la modernidad y al progreso que representaban quienes fijaban estos símbolos de identificación (Velasco Maillo 1990). Los trajes de una Asturias rural, que rápidamente se transformaba con la llegada de la industrialización y la minería, pasaron a ser un elemento iconográfico de un mundo que, al mismo tiempo que evolucionaba por los cambios traídos por el progreso, se enaltecía como ejemplo de los virtudes inmutables de un pasado y de un carácter honrado y de principios prístinos que sucumbían ante los males traídos por el desarrollo, tal y como lo narró Armando Palacio Valdés en su conocida novela La aldea Perdida (Palacio Valdés 1903: 3).

Sí, iyo también nací y viví en Arcadia! También supe lo que era caminar en la santa inocencia del corazón entre arboledas umbrías, bañarme en los arroyos cristalinos, hollar con mis pies una alfombra siempre verde. Por la mañana el rocío dejaba brillantes gotas sobre mis cabellos; al mediodía el sol tostaba mi rostro; por la tarde, cuando el crepúsculo descendía de lo alto del cielo, tornaba al hogar por el sendero de la montaña y el disco azulado de la luna alumbraba mis pasos. (...) La Arcadia ya no existe. Huyó la dicha y la 
inocencia de aquel valle. ¡Tan lejano! ¡Tan escondido rinconcito mío! Y sin embargo, te vieron algunos hombres sedientos de riqueza. Armados de piqueta cayeron sobre ti y desgarraron tu seno virginal y profanaron tu belleza inmaculada. ¡Oh, si hubieras podido huir de ellos como el almizclero del cazador dejando en sus manos tu tesoro!

Los protagonistas de este proceso de fijación de la indumentaria del país asociada con una identidad histórica y cultural, se relacionan con las figuras que comenzaron con las primeras investigaciones folclóricas en la segunda mitad del siglo XIX, reunidas en torno a la figura de Fermín Canella y Secades y el grupo epistolar La Quinta$\mathrm{na}^{1}$. A este autor se debe el artículo de "De vita et moribus (usos y costumbres asturianas)" (Canella y Secades 1900) en la que se hace una descripción de las prendas que ya entonces se conocía como traje asturiano, cuya estandarización se había ido conformando en las décadas anteriores tanto en la iconografía, con especial lugar para los grabados de José Cuevas para la revista editada en Madrid entre 1878 y 1882 La Ilustración Gallega y Asturiana, como en la literatura. En la comedia en un acto y en prosa de Vital Aza titulada La Praviana, (Vital Aza 1896) el propio autor da una serie de indicaciones sobre cómo se deben representar los personajes que la protagonizan.

JULIA vestirá el clásico traje de aldeana de Asturias. En la cabeza, pañuelo de tul blanco con puntilla, anudado arriba; dengue negro, de raso ó pañete fino, ribeteado con cinta ancha de terciopelo, cruzado sobre el pecho y atado atrás; jubón ó justillo de brocatel, al que pueden ir pegadas las mangas de la camisa para facilitar el cambio de traje; refajo de pañete grana, adornado con algunas cintas de terciopelo negro alrededor; delantalito redondo y corto, de seda negra, adornado con encaje ó puntilla; los cordones de seda de colores con herretes, que figuren abrochar el justillo, caerán, formando una lazada, sobre el delantal; media blanca, calada; zapato bajo con lazo; pendientes y gargantilla de corales, y cadena de oro o doublé sobre el dengue, y sujetando en el pecho un alfiler ó medallón,

El traje de RAMONA será el siguiente: falda oscura de merino o percal; delantal grande y liso; pañuelo de merino, de colores vivos y con fleco, cruzado sobre el pecho y atado atras; chambra de percal; zapato bajo y media blanca, y pañuelo de seda de colores alegres, anudado sobre la cabeza. (sic)

En la obra, Ramona es una costurera de pueblo que viste de acuerdo a las modas populares del momento. Está preparando un traje de "aldeana asturiana" para el personaje de Julia. La descripción que hace el autor de esta ropas se ajusta con el estándar que ya se había fijado entonces para la mujer, y que contrasta con las ropas de cada día de la modista. Además, este personaje de Julia no es asturiano, sino una señorita acomodada de Madrid que quiere vestirse de este modo para acudir a las fiestas y romerías. En poco espacio Vital Aza recoge tanto la diferencia entre indumentaria tradicional y modas populares, como entre la cotidianeidad del atuendo diario y un traje singularizado que no solo es festivo, sino identificativo de una condición particular de "lo asturiano".

Ataviadas con las idealizadas ropas de las campesinas, numerosas mujeres vestidas al uso ennoblecido del "traje del país" posaron para la fotografía desde la década de

\footnotetext{
${ }^{1}$ Juaco López (2010), en su artículo "Antonio Machado Álvarez y Asturias. Once cartas inéditas de Machado Álvarez a Fermín Canella Secades. 1880-1884", explica las razones por las cuales no se pudo establecer una sociedad asturiana de folclore por la falta de interés de Fermín Canella, embarcado en su propio proyecto de La Quintana.
} 
los años Sesenta del siglo XIX, mostrando con el paso del tiempo las distintas interpretaciones que de los trajes populares se han sucedido en función de las diferentes coyunturas políticas y sociales por las que han pasado (Ortiz García 2012). De la misma manera, también desde fechas muy tempranas se pueden observar los retratos de niños y niñas vestidas con estas mismas indumentarias, en las que la liminaridad, el cumplimiento de un rito de paso es aún más evidente, cuando se coloca ante el objetivo de la cámara a unas criaturas ataviadas con ropas pertenecientes originariamente a gentes adultas, con elementos particulares del atrezzo como el palo para arrear el ganado o el reloj de leontina que adornaba el chaleco de los caballeros ${ }^{2}$. Unos críos que en otras condiciones vestirían de acuerdo con su edad y posición social, entre las clases populares con un sencillo mandilón, reutilizando ropas de hermanos y parientes de más edad y muchas veces descalzos.

Pero no hay hombres vestidos de asturianos. No es que no aparezcan fotografías de varones ataviados con trajes de calzón corto, la cuestión es que la mayoría de estos documentos fotográfico presentan a personas mayores a las que se retrata precisamente por la singularidad de llevar un atuendo antiguo, y por representar dentro de su propia sociedad elementos extraños a la norma común en el vestir. Así, el fotógrafo Federico Conde Caminero registró la imagen familiar de un hijo y su padre hacia 1895. El anciano viste el traje de calzón corto, chaqueta de corte inglés y montera común a las clases populares cuatro décadas antes. El joven lleva la interpretación que esas mismas clases hicieron del terno burgués de pantalón largo, chaqueta americana y sombrero, boina o gorra cachucha. En la segunda imagen, el ingeniero de minas inglés Willian Selkirk fotografió a otro anciano en Cangas de Onís por las mismas fechas, junto a un hombre joven vestido de acuerdo a lo común entre las clases populares en aquel momento, la de una Asturias transformada por la industrialización. Aquí se destaca la rusticidad del traje de calzón corto, de recio tejido de lana, en contraposición a la indumentaria más moderna de tejidos de algodón. Según ya escribió la autora de este artículo (Santoveña 2013: 27) refiriéndose a este proceso de cambio en la composición social de la región:

Este nuevo hombre, menos atado al terruño, se va imponiendo poco a poco, al mismo tiempo que las nuevas oportunidades de trabajo van creando ocupaciones mixtas entre la industria y la labranza, que rápidamente logran que la reciente moda masculina —no solo unas ropas, sino toda una idea de hombre- se vaya imponiendo, aun conservando en algunos lugares partes de una indumentaria con la que los varones ya no identifican su masculinidad. Usar pernera larga significa ser un hombre moderno, adoptar un símbolo de triunfo y de adecuación a los nuevos tiempos. Usar calzón corto es permanecer anclado en una forma de vida que se extingue. El sincretismo entre ambos puntos de vista se mantendrá a lo largo de décadas y se puede comprobar cómo en el mundo campesino que acepta la nueva indumentaria conservará, sin embargo, la montera, la faja y el palu, que se irán perdiendo poco a poco y en ese mismo orden.

Siguiendo la paradoja planteada por Velasco Maillo, el burgués que busca su identidad en lo popular no se viste con un traje asociado a lo atrasado y pueblerino.

\footnotetext{
${ }^{2}$ Durante el viaje de la familia real a Asturias en 1858, se le obsequiaron a los infantes Isabel y Alfonso sendos trajes de "campesinos asturianos", como cuenta Juan de Dios de la Rada en su crónica. El Príncipe de Asturias se retrataría con el suyo unos años después. Las primeras fotografías de niños vestidos de asturianos proliferan a partir de este retrato de la casa real.
} 
IMAGEN 1.-Mujer vestida con traje asturiano. Ramón del Fresno. Oviedo. Carta de visita. Hacia 1865. Fototeca del Muséu del Pueblu d'Asturies. N. ${ }^{\circ} 29.201$.

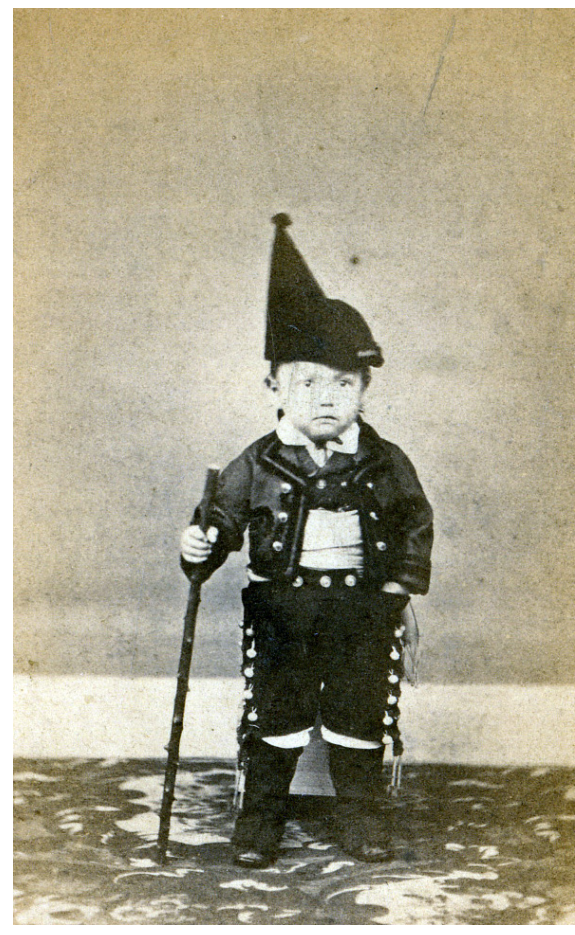

IMAGEN 2.-Niño vestido con el traje asturiano. Carta de visita. Fototeca del Muséu del Pueblu d'Asturies. N. ${ }^{\circ} 9.509$.

IMAGEN 3.-Retrato de familia en que los niños visten con mandilones o ropas reutilizadas de los adultos. Destaca el bebé en brazos de la madre que aparece desnudo. Tarjeta americana. Fototeca del Muséu del Pueblu d'Asturies. N. ${ }^{\circ} 27.293$.
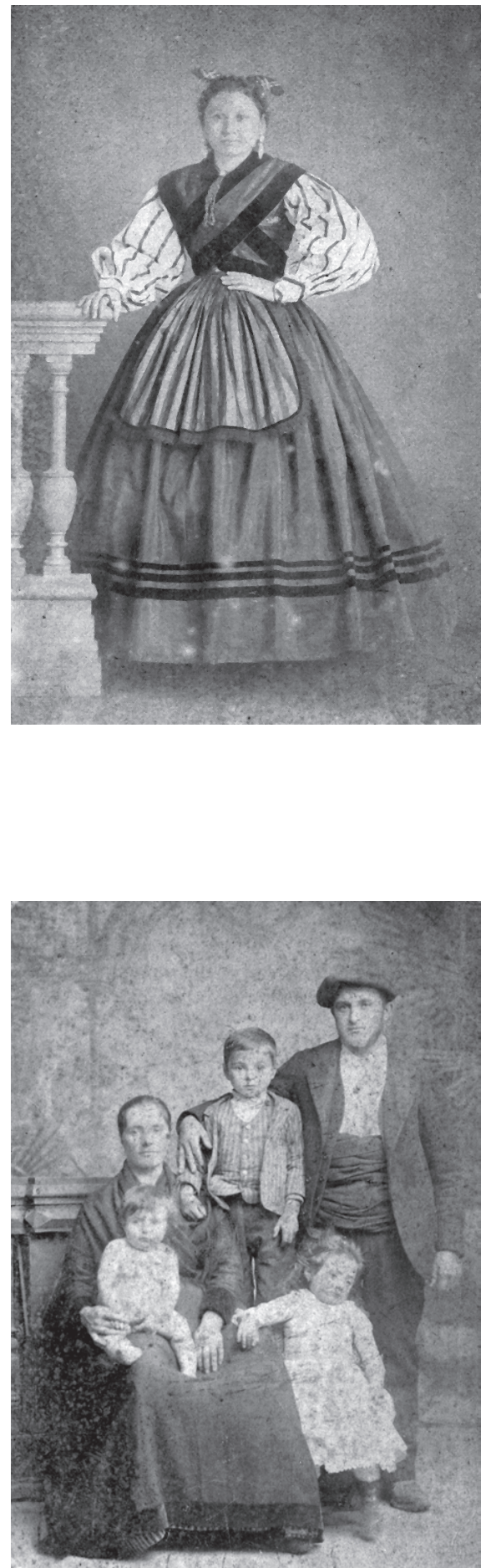
Noticias de gaiteros vestidos con traje asturiano desfilando por Oviedo ataviados a la usanza del país se recogen ya en la década de los años $1860^{3}$. Baltasar Cué fotografió en 1893 la estampa de Ramón García Tuero, El Gaiteru Libardón ${ }^{4}$, y su acompañante al tambor, revestidos intencionalmente con un traje asturiano para acompañar los actos festivos del día de San Roque en la villa de Llanes. La pareja de gaita y tambor primeramente y más tarde — con la aparición de las series de tarjetas postales con tipos y temas populares a principios del siglo XX- los integrantes de grupos folclóricos y asociaciones corales, serán una presencia frecuente en los retratos de hombres vestidos de asturianos, estableciendo desde finales del siglo XIX una estrecha relación entre el traje asturiano y las manifestaciones del folclore. Lo que llama la atención es que aquella élite cultural burguesa, masculina y académica, que había fijado el traje asturiano como elemento identitario, no se reviste a si misma con esa prenda de identificación para hacerse un retrato. El contrasentido de la conformación de una identidad asturiana continúa. Si bien se contrata y se celebra - también en algunos casos se detesta, como bien apunta Fonsu Fernandez García (Otero Vega et al. 2011) - a estos miembros de la sociedad que se visten y representan una parte de lo que se entiende como "tradiciones asturianas", y por lo tanto elementos claves de su identidad, no dejan de ser gentes de clase baja y marginal en su propia condición de músicos populares.

\section{ASTURIANOS EN AMÉRICA}

A esta ausencia fotográfica de hombres "vestidos de asturianos", se opone una importante excepción en las décadas finales del siglo XIX. La constituye un reducido pero significativo grupo de imágenes llegadas de allende el mar. Francisco Crabiffosse (Crabiffosse 2000: 45) en la el libro Asturianos en América (1840-1940). Fotografía y Emigración escribe:

Los fotógrafos no dejaron pasar la oportunidad de ganar nuevas clientelas e insertaron publicidad destinada a todos aquellos que quisieran retratarse con el traje regional, estableciendo precios especiales y en el caso de Teodoro Pumariega, con delicadas iluminaciones.

El texto en que se anunciaba esta oferta está también reseñado por el autor, que lo tomó del Eco de Covadonga de La Habana, del 25 de octubre de 1884. Dice así:

Según nos Participa el astur Pumariega, fotógrafo de la calle O'Reilly, a todos aquellos que a su casa vayan a retratarse con el traje característico de sus provincias, les regalará un bonito retrato iluminado a la acuarela, sin que por esto haya aumentado el precio de costumbre. Ya lo sabéis: una docena de imperiales nueve pesos en billete y además el iluminado para enviarlo a la tierra. Allí iremos todos.

\footnotetext{
${ }^{3}$ En el periódico La Prensa, del domingo 24 de septiembre de 1933 y bajo el título "En Quirós nació un gaitero", se le hace una entrevista a José Álvarez, un instrumentista natural de este concejo y que en aquel momento contaba con 76 años de edad, el cual recuerda vívidamente desfiles de gaiteros vestidos de asturianos en su niñez.

${ }^{4}$ Se conservará la palabra gaiteru para denotar la especificidad asturiana de estos músicos, frente a otros intérpretes de gaita del resto de España.
} 
IMAGEN 4.-Retrato de padre e hijo y en el que se aprecia el cambio de las modas masculinas ocurrido a mediados del siglo XIX en Asturias. Federico Conde Caminero. Oviedo. Tarjeta americana. Hacia 1895. Fototeca del Muséu del Pueblu d'Asturies. N. ${ }^{\circ} 9.067$.
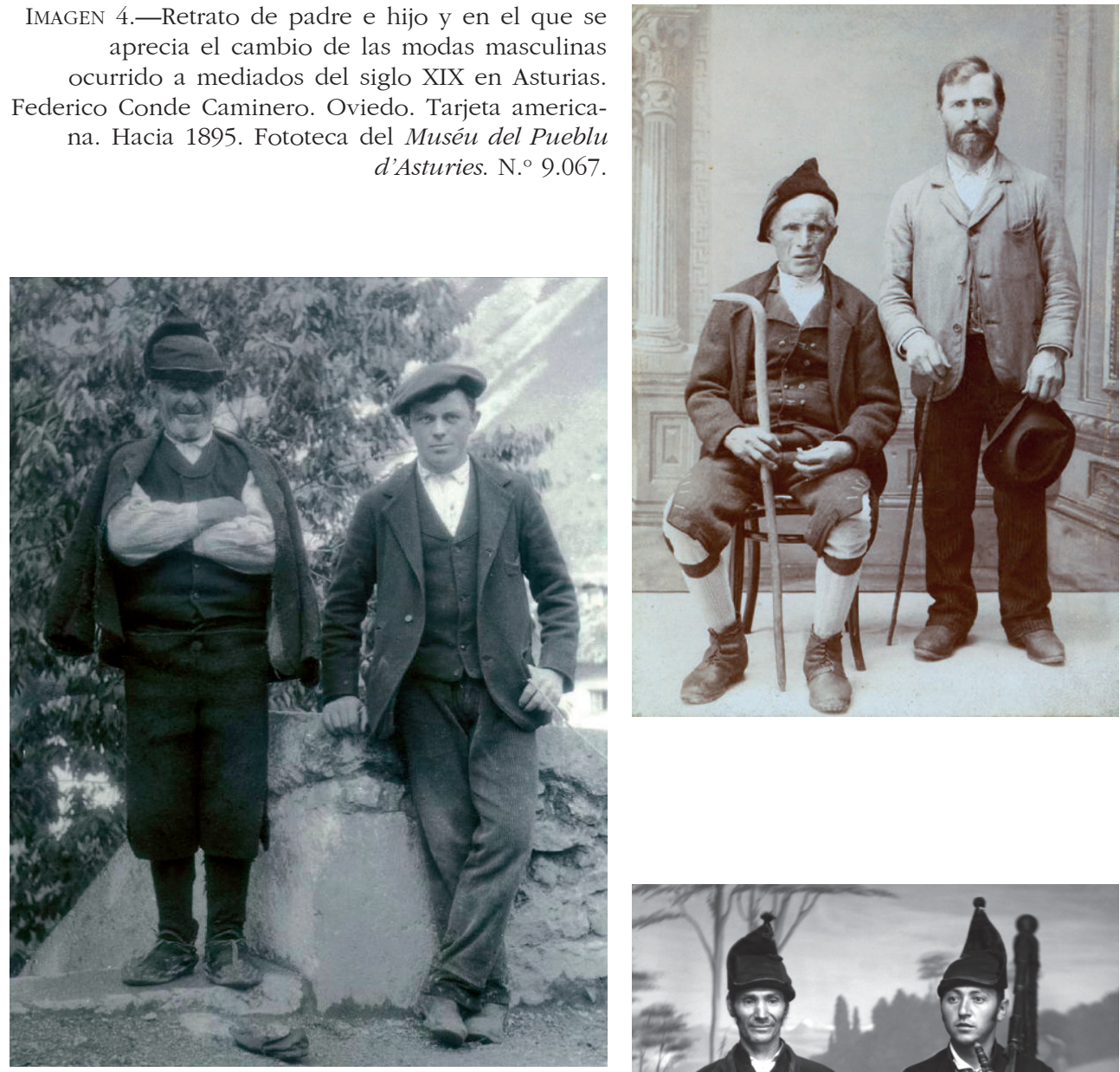

IMAGEN 5.-Anciano vestido de acuerdo a las modas de comienzos del siglo XIX, junto a un joven con el terno de pantalón largo utilizado por las clases populares a finales de ese mismo siglo. William Selkirk. Cangas de Onís. Hacia 1895. Álbum de fotografías. Fototeca del Muséu del Pueblu d'Asturies. N. ${ }^{\circ} 35.554$.

IMAGEN 6.-Pareja de gaita y tambor. Ramón García Tuero "El Gaiteru Libardón" y un tamboriteu desconocido, vestidos con el traje asturiano. Baltasar Cué. Llanes. 1894. Reproducción contemporánea sobre una placa de vidrio. Fototeca del Muséu del Pueblu d'Asturies. N. ${ }^{\circ} 9.067$.

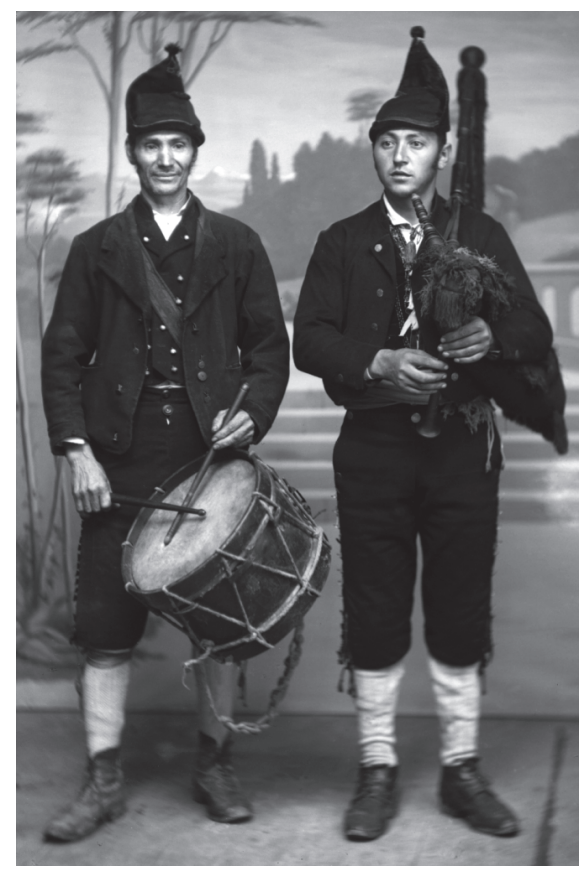


Dos fotografías con dedicatoria manuscrita dan cuenta del gusto por retratarse vestidos de asturianos. En la primera un hombre se retrata en el estudio de J. A. Suárez, en la misma calle O'Reilly en la que estaba el estudio de Pumariega. En el reverso manuscrito se lee: "Recuerdo de la romería asturiana dedicado a mi distinguido amigo Don Adolfo Palacio. Habana diciembre-7-84”. En la fotografía inventariada de un mozo acompañado de una jovencita y una niña también vestidas de asturianas, tiene esta otra dedicatoria: "Recuerdo de la romería asturiana que dedico a mi amigo don Francisco García. G. Pumariega. Enero de 1885".

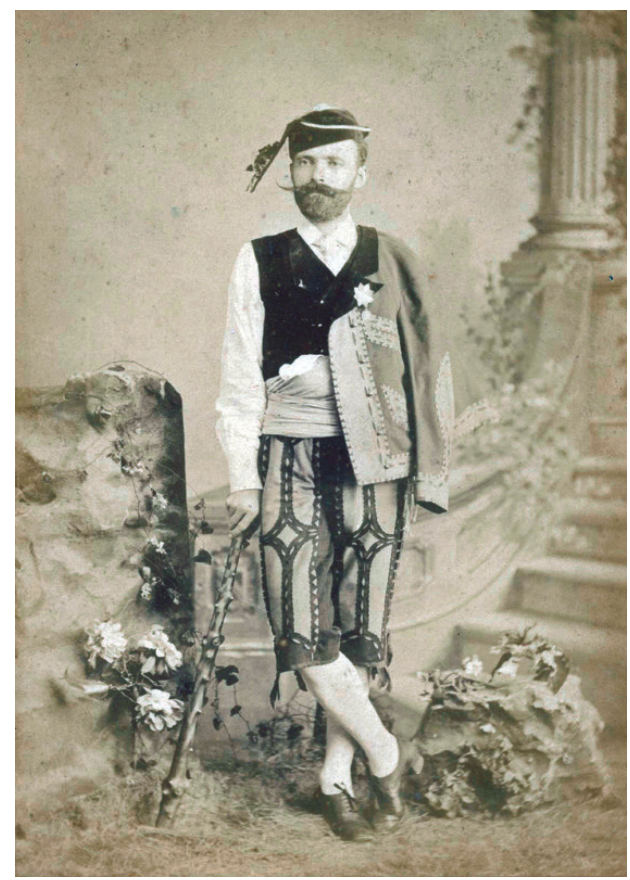

IMAGEN 7.- - Retrato de un hombre vestido de Asturiano fotografiado en La Habana. Reverso manuscrito: Recuerdo de la romería asturiana dedicado a mi distinguido amigo Don Adolfo Palacio. Habana diciembre-7-84. La chaquetilla remite a los diseños de sobrepuestos, trencillas y alamares de las pellizas de la caballería. Suarez fotógrafo. La Habana. Tarjeta americana. Fototeca del Muséu del Pueblu d'Asturies. N. ${ }^{\circ} 34.543$.

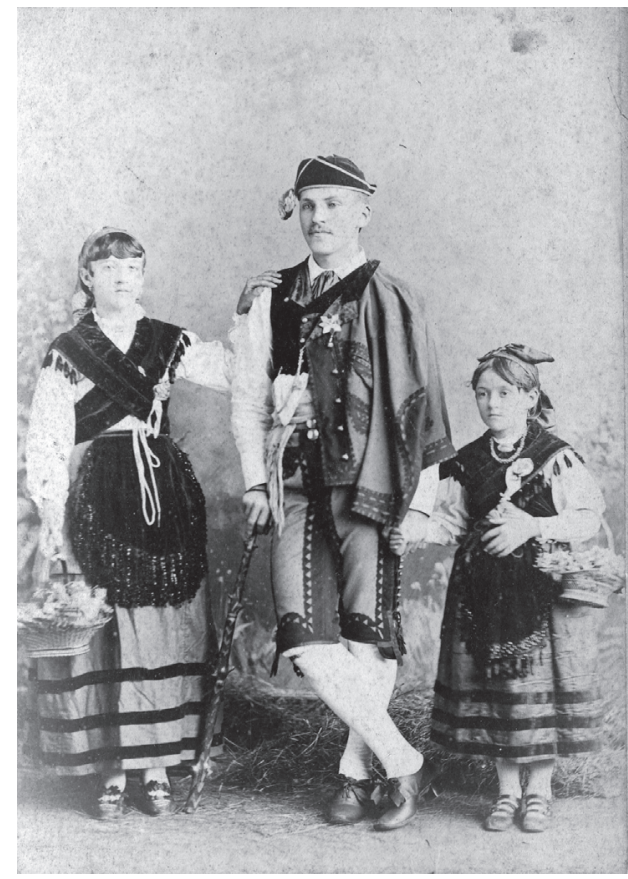

IMAGEN 8.--Retrato de una mujer, una niña y un hombre vestidos de asturianos. Reverso manuscrito: Recuerdo de la romería asturiana que dedico a mi amigo don Francisco García. G. Pumariega. Enero de 1885. Teodoro Pumariega. La Habana. Tarjeta americana. Fototeca del Muséu del Pueblu d'Asturies. N. ${ }^{\circ} 29.513$.

Cinco años después esta misma forma de interpretar el traje asturiano se documenta en México. En este caso la dedicatoria identifica también al fotografiado: "Recuerdo de amistad sincera a Cayetano Rubín de Celis. Andrés Toriello. Octubre de 1890». Todos ellos tienen la misma postura, con el cuerpo relajado apoyado en el palu, un pie cruzado por delante del otro y la chaqueta terciada sobre el hombro. Una pose de estu- 
dio asociada con una indumentaria y una identidad asturiana. A este mismo Cayetano Rubín de Celis lo vamos a encontrar encabezando el listado de caballeros vestidos a la asturiana que protagonizan las fotografías tomada en Coapa en México, en 1890, con motivo de una romería asturiana; razón común a todos ellos tanto en Cuba como en otros lugares, y que les da motivos para lucir el traje de la patria lejana.

\section{ASTURIANOS EN CUBA}

Los trajes americanos son un ejemplo de un manierismo indumentario ajeno a las descripciones e imágenes que se tienen del traje asturiano en la propia Asturias. El calzón aparece profusamente adornado con remontas de color bien diferenciado, formando llamativas figuras geométricas. Las chaquetas, sobre todo en las de Cuba, van también abundantemente adornadas, con sobrepuestos en tela de diferente colorido y pesadas botoneras que recuerdan el historicismo decorativo de las chaquetas militares de húsares y dragones. Si se considera el prestigio de los uniformes y de su influencia en la moda masculina, esta coincidencia puede ser clave en la interpretación de esta indumentaria. La colonia asturiana en Cuba ya era importante antes de la primera

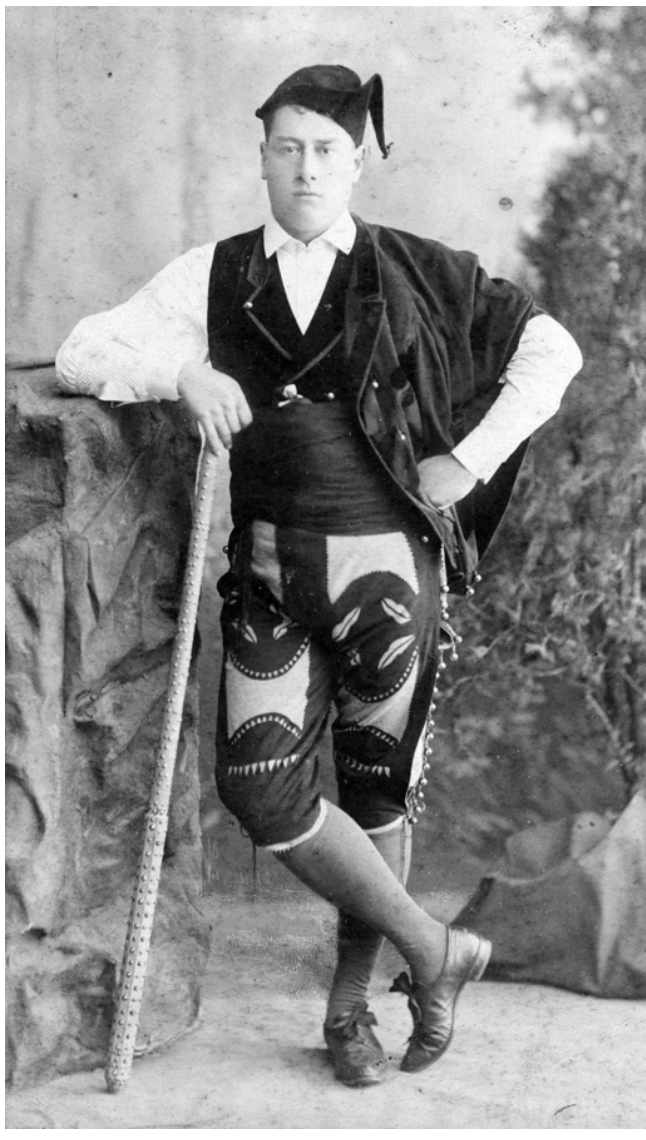

IMAGEN 9.- - Retrato de Andrés Toriello vestido de asturiano. Reverso manuscrito: "Recuerdo de amistad sincera a Cayetano Rubín de Celis. Andrés Toriello. Octubre de 1890". Valleto y Cia. México. Tarjeta americana. Fototeca del Muséu del Pueblu d'Asturies. N. ${ }^{\circ} 17.758$. guerra de independencia —entre 1869 y 1880 - y Francisco Erice (2013: 147-165) destaca la importancia de las tropas de voluntarios asturianos en esta época y el sentimiento españolista de la colonia emigrante. El historiador cubano Ismael Sarmiento Ramírez (1999: 226) señala refiriéndose a las fiestas que organizaban los asturianos en Cuba que en este período histórico:

"[...] afirman un marcado españolismo que está muy vinculado a los intereses de la Corona. La imagen de la Virgen de Covadonga preside los principales actos públicos de la comunidad asturiana en la Isla y su veneración es acción casi obligada en las diferentes asociaciones benéficas formadas por los hijos de la región. En la esfera militar, el Principado aporta a la Guerra de Cuba el denominado Batallón de los Cazadores de Covadonga, lográndose de este modo una mayor conciliación entre la manifestación religiosa y las aspiraciones patriótico-militares de los asturianos". 
La falta de respuesta de la fototeca de Cuba ante las reiteradas solicitudes hechas para consultar sus fondos, con respecto al tema que se trata en este artículo, no permite tener una imagen más completa de militares españoles en la isla con la uniformidad de la época, al desconocer si en sus catálogos se hallan fotografías de soldados coloniales retratados durante este primer periodo de la independencia cubana con el uniforme específico de húsares de caballería. Tampoco se ha podido obtener información, por tanto, de más documentos gráficos de emigrantes vestidos de asturianos que puedan estar depositadas en este fondo. De la existencia de fotografías del periodo bélico da buena cuenta el Albúm Histórico y Fotográfico de la Guerra de Cuba desde su principio hasta el reinado de Amadeo I (Gelpi y Ferro 1872), ilustrado con imágenes del fotógrafo Leopoldo Valera Solís o las de Elías Ibáñez incluidas en el $\bar{A}$ lbum de la paz citado por Antonio David Palma Crespo en su artículo «Enrique Facio y el nacimiento de la fotografía de guerra en España" (2014: 298-324) y que se refiere a la firma del tratado de Zanjón en 1878, mediante el cual se pondría fin a la primera insurrección cubana, previo a la llamada Guerra Chiquita.

Sin embargo, la fototeca de la Biblioteca Nacional de España ofrece algunos documentos de aquel período con imágenes de uniformes de gala. Así mismo se pueden consultar otros fondos como la Fototeca del Muséu del Pueblu d'Asturies, donde se conservan varias fotografías que permiten comprobar mediante los retratos de militares, la vistosidad de las indumentarias utilizados por el ejército español. La primera es un dibujo de los húsares de la Princesa en 1859, tomada del foro de la Policía Nacional y en él se aprecian tanto los coloridos como los abigarrados adornos que llevaban el dolmán y la pelliza. La segunda imagen corresponde a una litografía de Enrique Pio de Borbón fechado en 1879 en el que aprecian los adornos del dolmán, tanto en la pechera como en las remontas de la bocamanga. Las otras corresponden a la citada Fototeca de Asturias; la primera es un retrato de medio cuerpo en el que

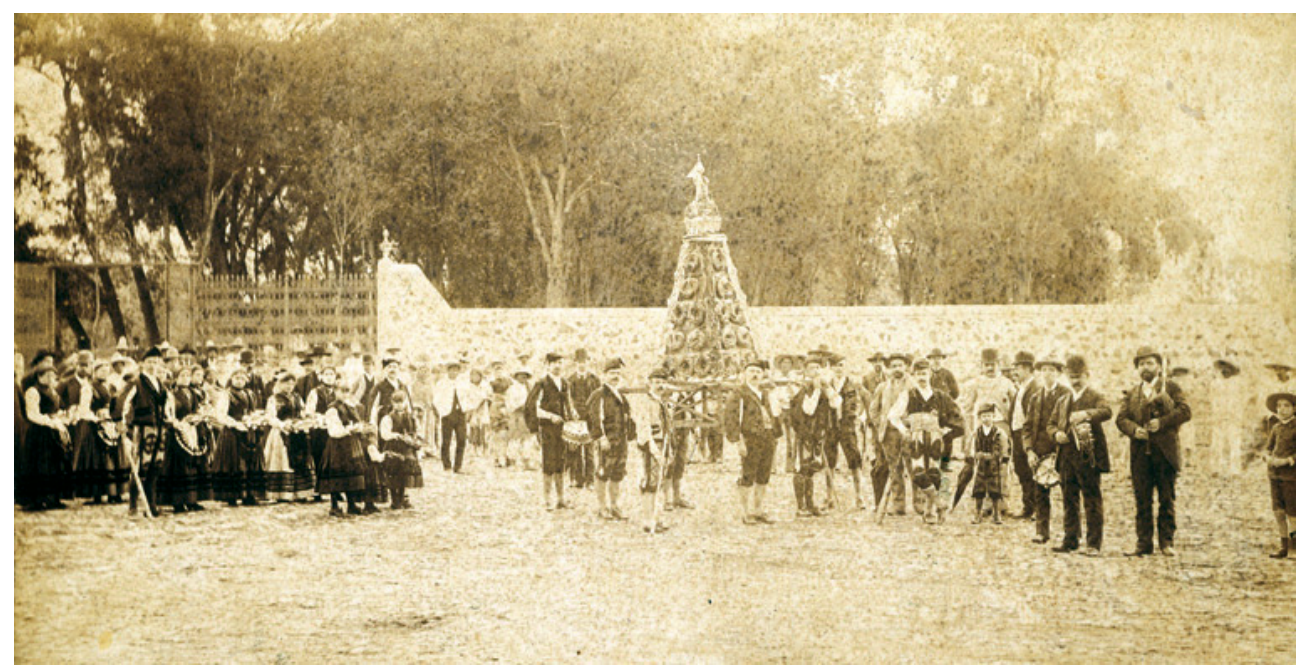

Imagen 10.-Fiesta asturiana en la finca Coapa en México en 1890, con motivo de la celebración de la Virgen de Covadonga. Cortesía de Juan Alfonso Fernández García. 
IMAgEN 11.-Dibujo de los Húsares de la Princesa en 1859, uno de los cuerpos del ejército de caballería que actuó en Cuba durante la Guerra de los Diez Años. Foro de la Policía Nacional. <https://www.foropolicia.es/foros/ uniformes-militares-t82016-30.html>.
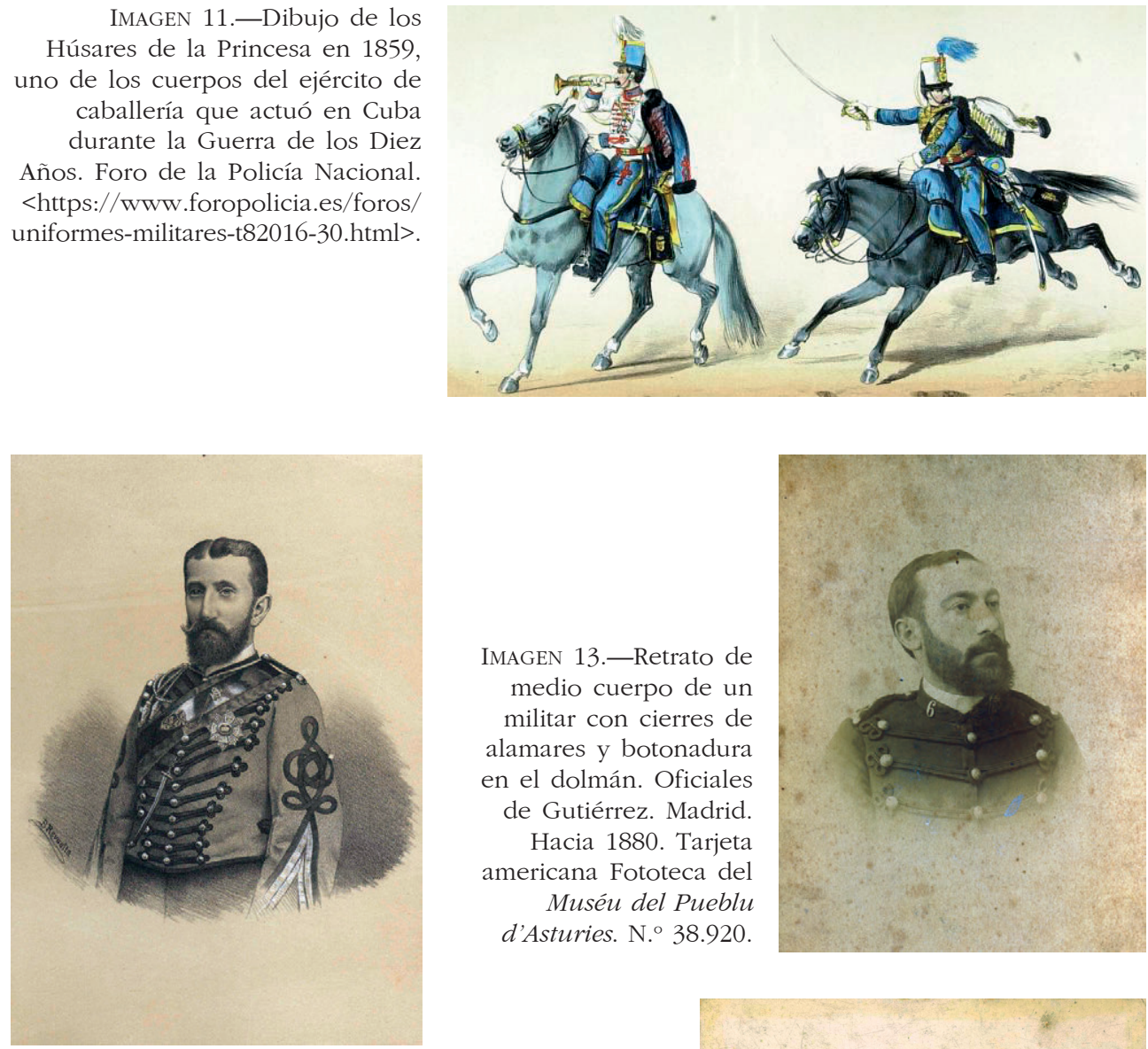

IMAGEN 13.- Retrato de medio cuerpo de un militar con cierres de alamares y botonadura en el dolmán. Oficiales de Gutiérrez. Madrid.

Hacia 1880. Tarjeta americana Fototeca del Muséu del Pueblu d'Asturies. N. ${ }^{\circ} 38.920$.

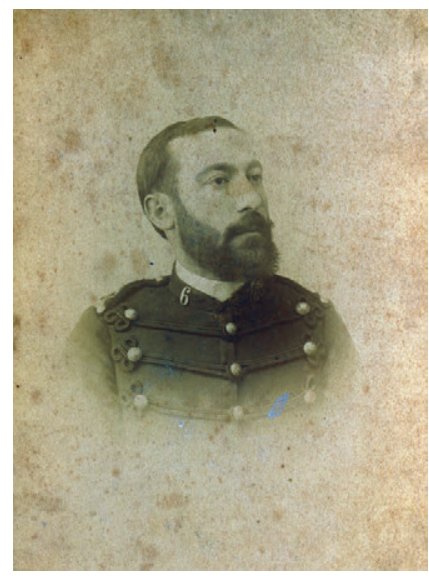

IMAGEN 12.-Grabado de Enrique Pío de Borbón, con el dolmán adornado con alamares y botonaduras en el pecho así como en la manga. 1879. Biblioteca Nacional de España. bdh0000025108.

IMAGEN 14.-Fotografía de un teniente de caballería, con una pelliza adornada con remontas de astracán y grandes alamares. Enrique Marquerie. Gijón. Hacia 1895. Tarjeta americana. Fototeca del Muséu del Pueblu d'Asturies. N. ${ }^{\circ} 37.192$.

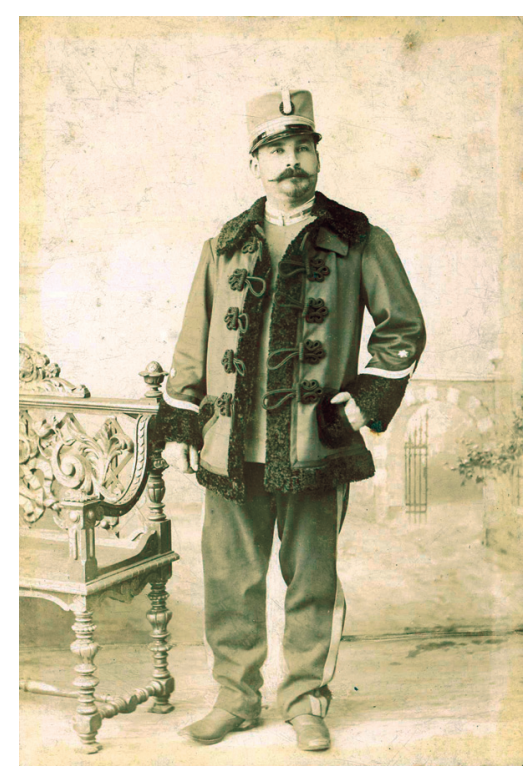


de nuevo se aprecian los detalles de las pasamanerías y botonaduras que adornan el uniforme en la década de 1880. La segunda está firmada por Enrique Marquerie en Gijón; en ella aparece un teniente de caballería ataviado con las llamativas pellizas que caracterizaban a estos atuendos. Si bien la fotografía se fecha hacia 1895, el conjunto de las cuatro ilustraciones muestra cómo las características estéticas se enlazan en el tiempo, manteniendo una unidad estética que se mantendrá hasta bien entrado el siglo XX, y por lo tanto constituyeron la referencia inmediata para la construcción de un traje asturiano singularizado en Cuba, en el que se sintetizarían las características de la tradición heredada de las modas populares de principios del siglo XIX en Asturias y la influencia de la moda militar.

El traje asturiano es obviamente usado para mostrar la tierra de donde procede quien lo lleva; al igual que ocurría con las fiestas a las que, según consta en las dedicatorias de las fotografías, acudían ataviados con esta destacada indumentaria. Según escribe Juaco López (1993: 53):

Las fiestas no sólo actuaban como un elemento de unión y diversión de los emigrantes asturianos, sino también como un elemento de identificación con un origen y una cultura comunes. Es por ello que en estas celebraciones se intentaba rememorar una romería asturiana.

Unos festejos que a pesar de esta primera intención de ser un reflejo de las que tenían lugar en la tierra de origen, muy pronto dieron muestras de la hibridación cultural producida entre los rememoración de la Asturias lejana con sus bailes, su música de gaita y la sidra como bebida referente, y las costumbres locales cubanas, según explica el autor antes citado (ibid.: 59):

[...] no obstante las convocatorias tenían más de ilusión que de realidad, pues, aunque los anuncios rebosaban de asturianía y localismo, la música y los bailes cubanos, eran los preponderantes en las fiestas asturianas, y lo mismo ocurría en Argentina y otros lugares.

Nos encontramos, pues, ante una reinterpretación de un traje para una nueva identidad, la del emigrante que se instala en un país que acaba de pasar por los dos primeros episodios de la guerra de independencia de la colonia, que reúne en su vestido elementos de la Asturias que dejó atrás y de la Cuba que se apacigua tras un período bélico, juntando las tradiciones del país de origen y la reciente historia militar de la colonia. El resultado de esta es un ropaje muy barroco lleno no solo de los referentes que denotan una influencia castrense, sino también de detalles feminizantes ausentes en la indumentaria original, como las remontas coloridas, los zapatos cerrados con lazos más propios de las mujeres que los sobrios cordones masculinos, así como la profusión de pespuntes llamativos, junto con los detalles floreados en las monteras. Las medias son de colores fuertes y se buscan también telas de tejido vistoso.

Al contrario de lo que ocurría en la Asturias, aquí la connotación de traje asociado con lo rural o lo atrasado está ausente. El emigrante no siente vergüenza ante el uso de un traje anticuado; por el contrario, lo reivindica y lo reinterpreta tomando características de reputados uniformes para transformarlo en un elemento de prestigio. Mediante su uso, muestra tanto su identidad asturiana como su condición de pertenencia a una comunidad emigrante. En este caso, "vestirse de asturiano" refuerza los lazos con la patria lejana de la que se siente orgulloso, al mismo tiempo que crea 
elementos de cohesión entre la comunidad emigrante. Aquí las connotaciones de marginalidad que se daban en Asturias al asociarse su uso entre los hombres adultos con las manifestaciones folclóricas, no sólo no aparecen sino que su importancia como elemento para la celebración festiva se potencia.

\section{ASTURIANOS EN MÉXICO}

Este mismo gusto por lo abigarrado se aprecia en México en 1890, dónde se puede ver el mismo barroquismo en los adornos, el cual no era ajeno al propio traje identitario de los mexicanos. El traje de los vaqueros, el conocido como traje charro, tiene su origen en los llamados "cuerudos", los trabajadores principales y responsables de ranchos dedicados a la cría de ganado vacuno y caballar. Como indumentaria particularizada ya se había identificado con un determinado sector de la población masculina, asociada al éxito económico y a un elevado estatus social. En la década de los años Cuarenta del siglo XIX presentaba un recargado adorno a base de alamares de plata en las chaquetas, cuyo origen es de nuevo las vistosas ropas de los húsares y dragones. Los acontecimientos políticos relacionados con la intención de instalar a Maximiliano de Austria como emperador de México, quien se presentó ante el pueblo vestido con uno de estos trajes en 1865, y los subsiguientes episodios revolucionarios, dotaron a esta indumentaria de un carácter de identificación nacional, relacionándola también con la expresión folclórica conocida como mariachi (Medina Miranda 2009).

Sin embargo, la fotografía de dos mozos tomada en este mismo país en 1900, muestra un cambio importante es su estética con respecto a las de los asturianos de una década antes. El gusto por los detalles abigarrados ha cambiado, no se busca el contraste de colores y las formas geométricas en calzón y chaqueta están ausentes; son las telas por sí mismas, con la riqueza del diseño y el colorido de su tejido, las que dan cierta imagen recargada. La mezcla de ele-

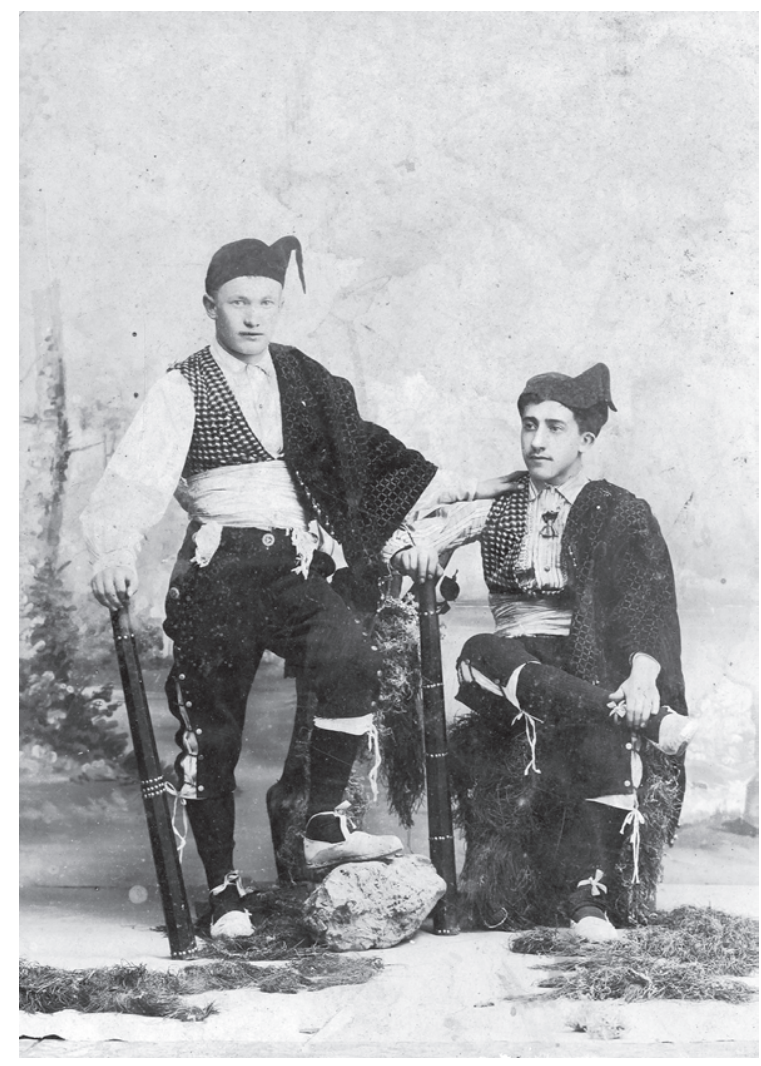

IMAGEN 15.-Dos mozos vestidos de asturianos. Reverso manuscrito: "Miguel Bustamante y familia. Recuerdo del día 8 de septiembre de 1900". Cordero y Bustamante. México. Fototeca del Muséu del Pueblu d'Asturies. N. 21.480. 


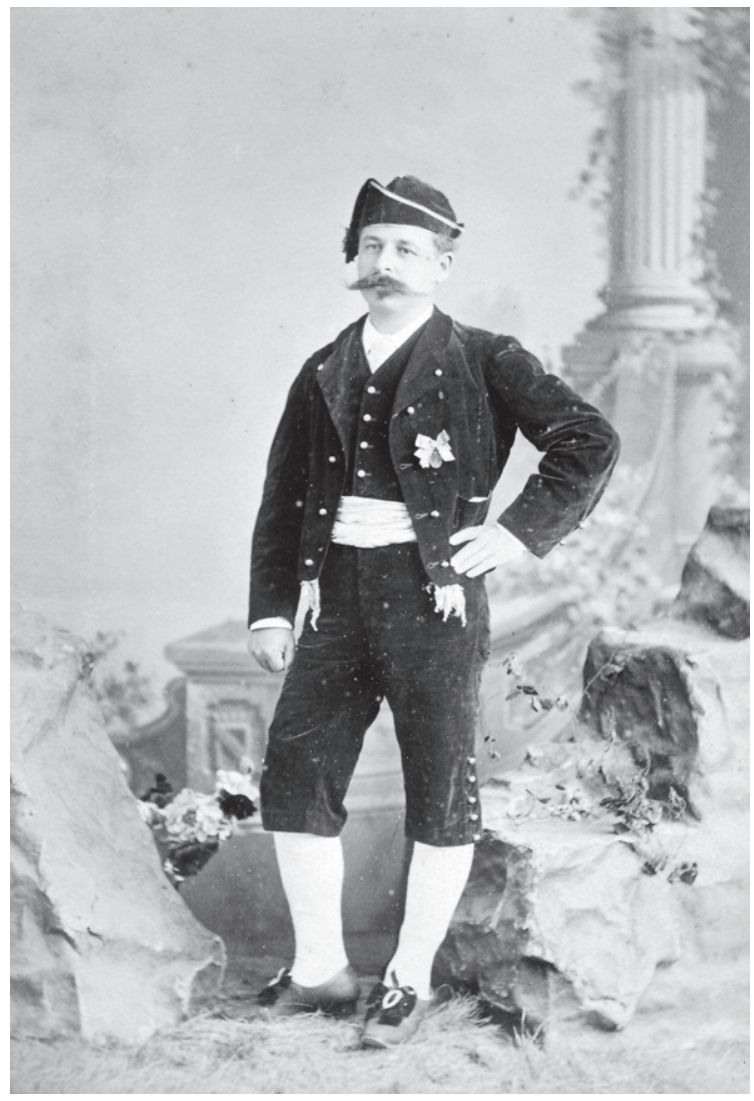

IMAGEN 16.-Hombre vestido de asturiano. Suarez fotógrafo. La Habana. Hacia 1895. Tarjeta americana. Fototeca del Muséu del Pueblu d'Asturies. N. 44.677. mentos que remiten a lo asturiano -el traje en sí mismo- y otros que hablan del mestizaje americano como las varas que llevan en la mano, que más recuerdan a un palo de lluvia que a un garrote o una vara de arrear el ganado, forma un conjunto diferente al que se veía en las imágenes anteriores. Elementos contemporáneos, las camisas de cuello por ejemplo, se incorporan a la indumentaria, junto a un calzado como las alpargatas que no estaba extendidas en las modas campesinas asturianas de principios del siglo XIX, aunque sí en las modas populares de finales de este siglo y en las primeras décadas del XX. En el reverso manuscrito figura una identificación, una fecha y un motivo: "Miguel Bustamante y familia. Recuerdo del día 8 de septiembre de 1900". El día de Nuestra Señora de Covadonga, el día de recordar a la patria chica, sus músicas, sus tradiciones y sus trajes, vistos y reinterpretados desde la distancia de quien ha emigrado, de quien vive ya una cultura híbrida entre la vieja y la nueva tierra, pero aun así mantie-

nen una voluntad de ser fotografiados con una indumentaria que les identifica como asturianos (García Canclini 1997).

En definitiva, y como tal recreación, el traje historiado y adornado que aquí se está tratando como elemento identitario en la emigración, parece una evolución localizada entre los emigrantes de Cuba y México en la década de 1880, que toman como referente el estilo de los uniformes, asociando elementos de prestigio militar con conceptos referenciales de la identidad como nación o patria, sin que por el momento haya un documento gráfico que indique que esta misma interpretación del traje asturiano se haya dado en otros focos de afluencia de las colonias asturianas allende el mar, e incluso en la propia Cuba esta forma particular del traje parece un momento modal pasajero. Una fotografía perteneciente también al Fondo del Muséu del Pueblu d'Asturies, tomada en La Habana hacia 1895, apunta a cierta relación con los conjuntos anteriores por la forma de la montera con su ala caída. El colorido del traje es mucho más sobrio, los adornos más contenidos y sólo los zapatos responden a una 
muestra del gusto anterior por el ornato, con lo que en un principio, parece que quedan atrás los llamativos trajes asturianos de la década anterior.

Cabe llegar a concluir que no solo hubo una forma de entender y reconstruir el traje asturiano en América, sino varias. Responderían tanto a los grupos de emigrantes que lo elaboraron, como a fechas diferentes en la historia del mismo en la emigración. Aun dentro de la continuidad, de la idea mantenida de llevar «un traje asturiano", los cambios han sido constantes y sujetos a los vaivenes ocurridos por igual en el país de emigración —aparición de centros asturianos, pérdida de contacto con la cultura original - como a los diferentes momentos modales en la indumentaria asturiana que han servido como guías ideales y orientativas, por no hablar de las hibridaciones impuestas por el contexto cultural del país de acogida del emigrante.

\section{EL TRAJE DE PORRUANU}

Con este nombre se conoce una indumentaria masculina que se documenta fotográficamente a principios del siglo XX y localizada particularmente en el concejo asturiano de Llanes. La propia denominación hace referencia a un pueblo perteneciente a este municipio, Porrúa, y como explicación del uso del mismo se ha argumentado que uno de los últimos en vestir traje de calzón corto fue un hombre de esta localidad, por lo que habría quedado asociado el nombre de porruanu con una tardía pervivencia de la indumentaria masculina de principios del siglo XIX. Yolanda Cerra recoge información con respecto a esta denominación relacionándola con la especificidad de la aldea de Porrúa debido a "La rusticidad de su paisanaje y su decisiva orientación ganadera" (Cerra Bada 2009: 179-205). Otra explicación diferente a la de un residuo indumentario, sería enlazar esta denominación con la cría de las ovejas y la existencia de un paño de calidad, llamando pañu porruanu, de donde se derivaría el que un traje de prestigio pasase a ser denominado como traje de pañu porruanu, deviniendo por economía lingüística en traje porruanu. García Mijares aseguraba en el siglo XIX (1990: 478) que:

[...] a comienzos del presente siglo existían sólo en la villa de Llanes más de doscientos telares, que daban ocupación a igual número de mujeres, de los que salían los envidiados lienzos de cáñamo o lino, las artísticas mantelerías; el sayal, el sayalín y las tan apreciadas mantas de Porrúa.

En su aspecto formal, en cualquier caso, el traje de porruanu se caracteriza por los adornos en tela negra a manera de remontas que se colocan en los calzones y la chaqueta, así como por los chalecos coloridos. Los adornos han evolucionado desde las primeras imágenes, pero manteniendo una unidad estética en el tiempo. Hoy vestir con este traje es parte del rito religioso de ofrendas florales conocido particularmente como ofrecimiento del ramu (Cerra Bada 2008: 169-179) y se proporcionan en las casas de alquiler igual que se hace con el traje de aldeana, denominación específica para el traje de mujer en esta comarca asturiana.

Independientemente de que en el imaginario popular pueda quedar la asociación de traje de porruanu, con cierta resistencia particular de los nativos de la aldea de Porrúa a abandonar la indumentaria de calzón corto, una serie de acciones sociales 


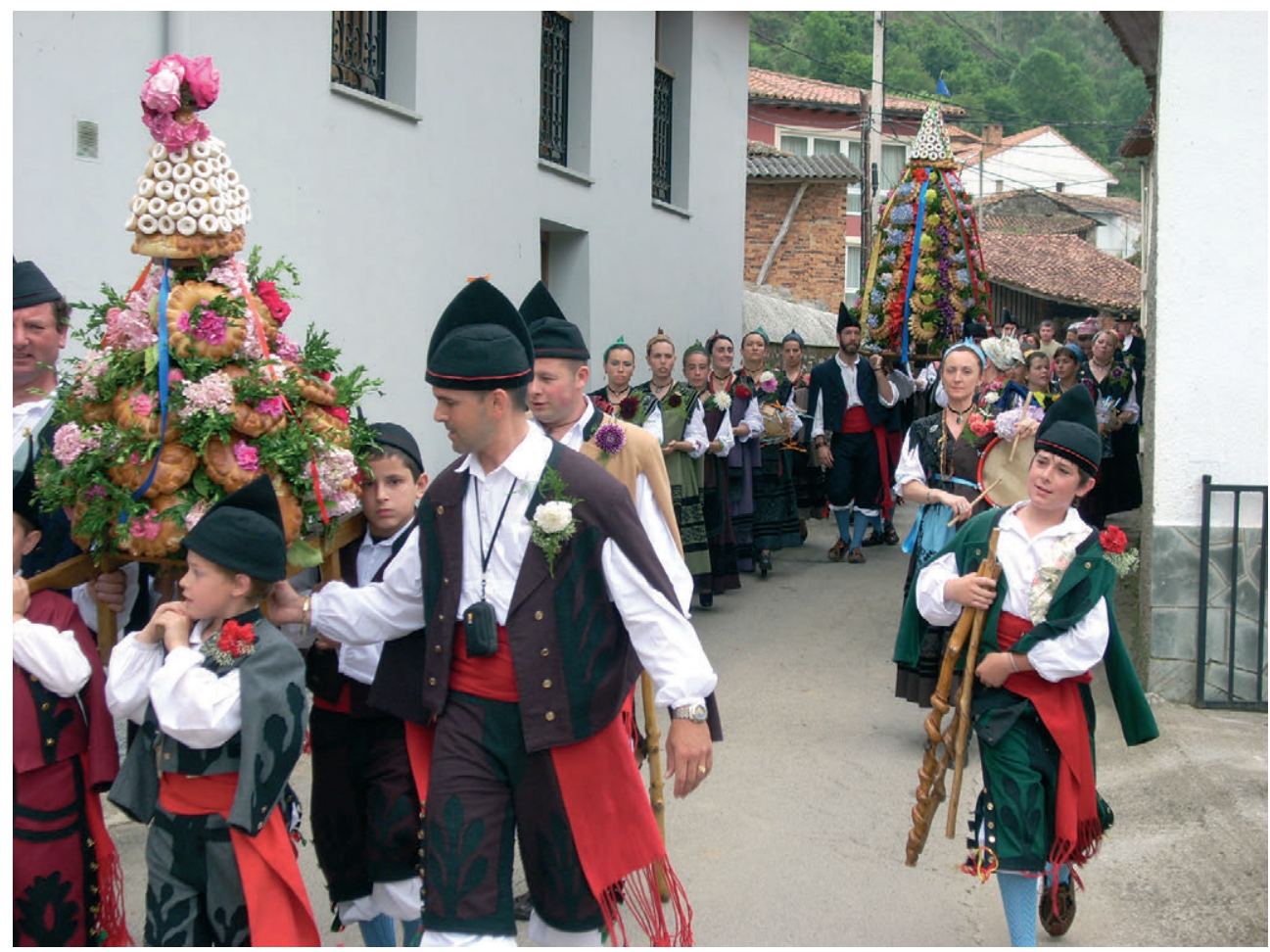

IMAGEN 17.- Niños y adultos vestidos de porruanu acompañando un ramu. Vibañu de Llanes. 2008. Fotografía de Fernando González. Soporte digital. Archivo personal de la autora.

ideológico-identitarias, apoyadas en un reducido número de fotografías, permiten plantear un inicio diferente para el singular atuendo de los llaniscos. Yolanda Cerra (2009: 179-205) reseña una información directa de Cayetano Rubín de Celis recogida por la autora en 1994, a punto de cumplir el informante 99 años, en la que relata: "de porruanu no se vestía nadie... Durante muchos años sólo se vestía el gaiteru de La Portilla. En cambio, en México, de esa época tengo yo una foto de mi padre", refiriéndose a las fotografías ya comentadas anteriormente de la fiesta celebrada en Coapa en 1890, y que habrán de tener una singular importancia en esta cuestión. Esta afirmación sobre que de porruanu no se vestía nadie, puede entenderse desde dos perspectivas diferentes. Una sería tomar esta indumentaria como una especificidad singularizada y separada de otras indumentarias tradicionales masculinas. La otra sería entender el término porruanu como la forma particular empleada en Llanes no solo para este traje concreto, sino para toda la acción por la cual un hombre se reviste de una determina identidad, la asturiana en general o la llanisca en particular mediante esta ropa; un acto que como vimos no tuvo especial predicamento entre los hombres a finales del siglo XIX y principios del XX salvo para cuestiones relacionadas con el folclore y la festividad, como indicaba Rubín de Celis señalando a Manuel Rivas, el Gaiteru la Portilla. 


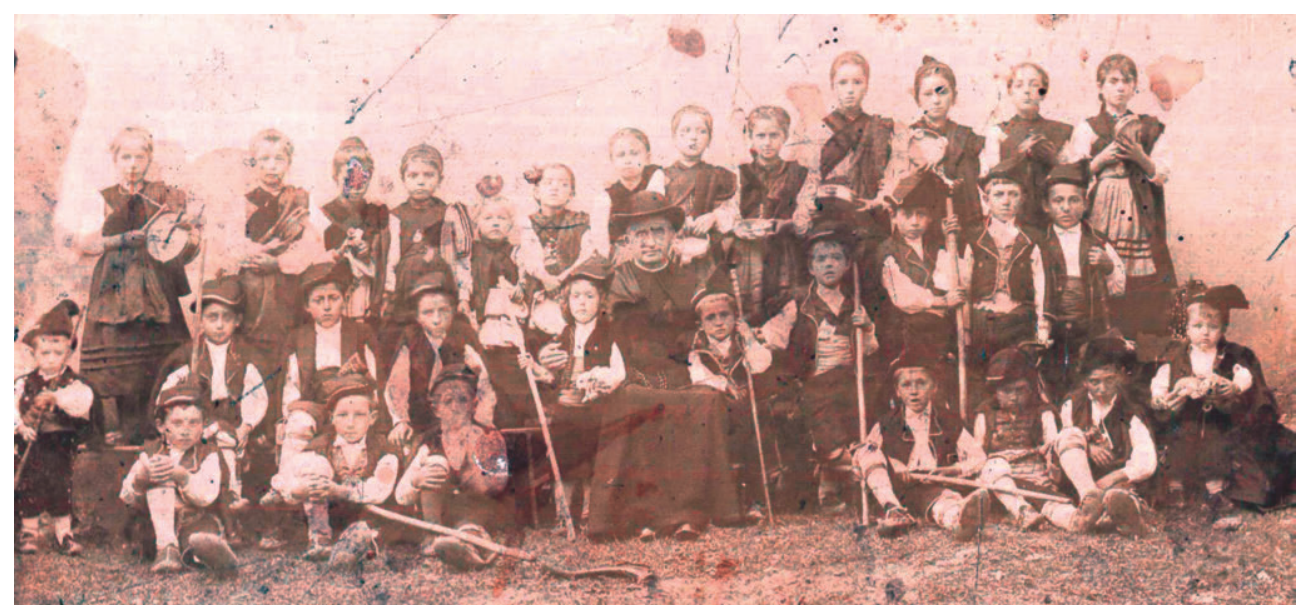

IMAGEN 18.-Ramu de niñas y niños rodeando a un sacerdote. Cándido García. Hacia 1895. Archivo del semanario El Oriente de Asturias.

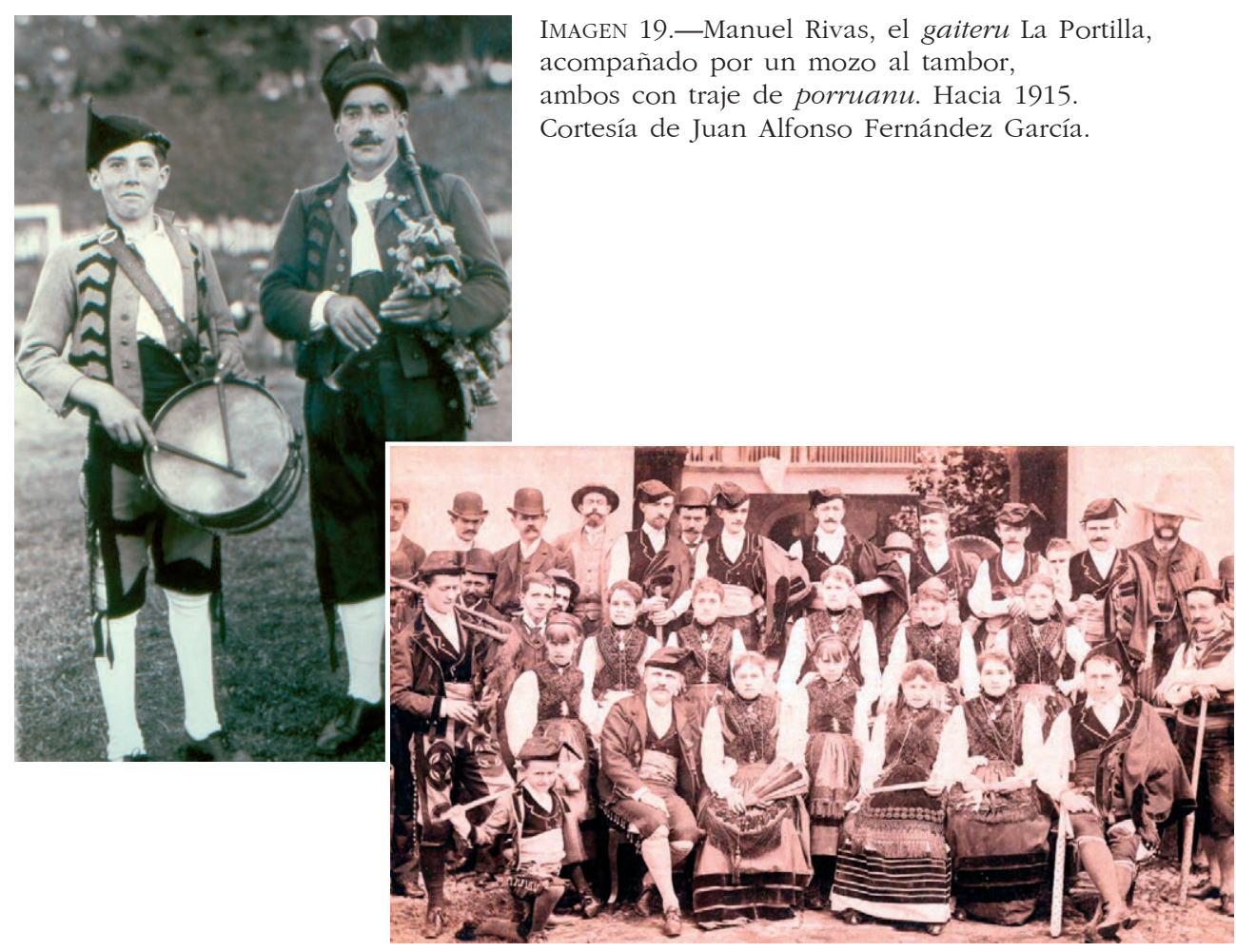

ImAGEN 20.-Asistentes a la fiesta de Coapa en 1890. Sentado primero por la izquierda Cayetano Rubín de Celis. También sentado pero primero por la derecha Andrés Toriello, el cual dedicaría una fotografía de estudio vistiendo con el mismo traje de asturiano a Rubín de Celis en octubre del mismo año. Archivo del semanario El Oriente de Asturias. 
Dos fotografías sirven para ilustrar este concepto separado de "traje asturiano" y traje de porruanu. En la primera se puede observar un ramu de niñas y niños, vestidas ellas con el traje de aldeana propio de la comarca y ellos de asturianos, entendido este atavío como cualquier otro que se pudiese encontrar en otra parte de Asturias, y siguiendo la costumbre instaurada tiempo atrás de vestir a los niños con esta indumentaria propia de los adultos. En la segunda aparece el citado gaiteru de La Portilla, con un traje adornado con remontas negras que se puede entender ya como de porruanu y diferenciado de otros trajes masculinos asturianos de calzón corto.

El conjunto de fotografías identificadas como pertenecientes a una fiesta del día de Covadonga celebrada en México el 8 de setiembre de 1890, y al que se viene haciendo referencia en los párrafos anteriores, es el que sirve como punto de partida para una hipótesis diferente sobre el origen de esta forma particular del traje asturiano de hombre en Llanes. En la fotografía reseñada con el n. ${ }^{\circ} 21$ el primer varón sentado por la izquierda es Cayetano Rubín de Celís, padre del informante citado por Yolanda Cerra. Su sobrio atuendo contrasta con los trajes historiados que llevan el resto de los participantes en la romería, particularmente el de Andrés Toriello, también sentado y primero por la derecha. Este gusto masculino por vestirse con un traje identificativo asturiano se corresponde con una corriente particular de estas fechas entre los emigrantes. Según Francisco Crabiffosse en su libro ya citado:

Ciertamente se puede hablar de una auténtica moda en estos años finales del siglo XIX, en la que el traje regional es empleado sobre todo por los varones como una clara afir-

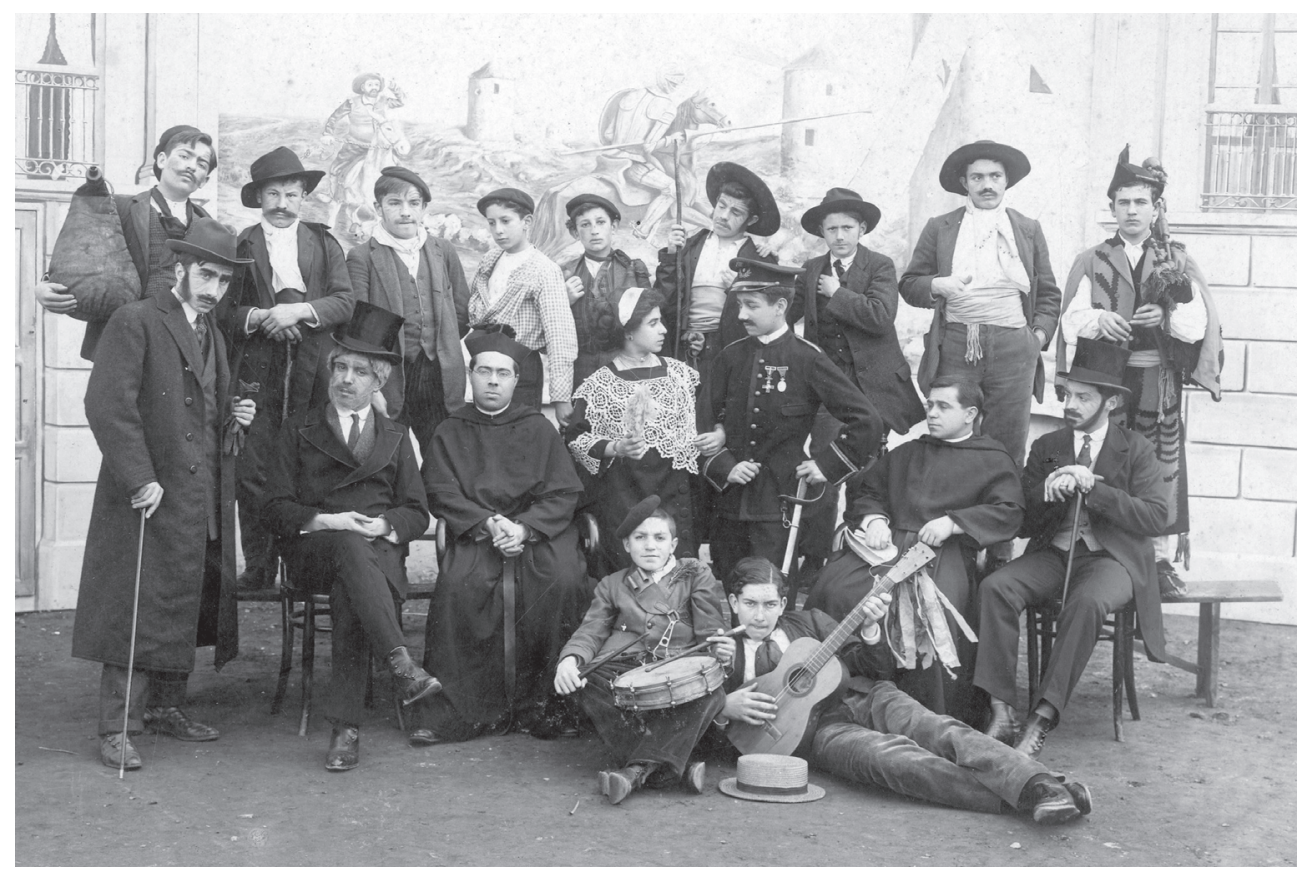

IMAGEN 21.-Francisco Álvarez Lavandera. "Pancho El Barrileru", en una fotografía atribuida a Baltasar Cue. Entre 1892 y 1894. Archivo del semanario El Oriente de Asturias. 
mación de su identidad asturiana, que se vincula con las reivindicaciones de origen romántico que influyen del mismo modo en la valoración de la lengua asturiana que se constata en la prensa de la emigración en este periodo.

Esta moda americana, de la que en su momento tuvieron conocimiento un grupo de llaniscos de visita en México y que participaron en actos de carácter religioso e identificativo con la tierra de origen - como el citado Rubín de Celis o el gaiteru Ángel Obeso, vestido con terno burgués en las fotografías- parecen haber influido directamente en los llaniscos que por circunstancias festivas y folclóricas usaban el traje asturiano. Lo que en un principio era la indumentaria empleada en un ejercicio de autoafirmación y solidaridad como colectivo, que reforzaba sus redes de cooperación mutua en los difíciles contingentes de la emigración, pasó a ser una forma particularizada del traje asturiano vinculada a las manifestaciones folclóricas llaniscas, siguiendo lo que ya era una costumbre habitual de relacionar mú-

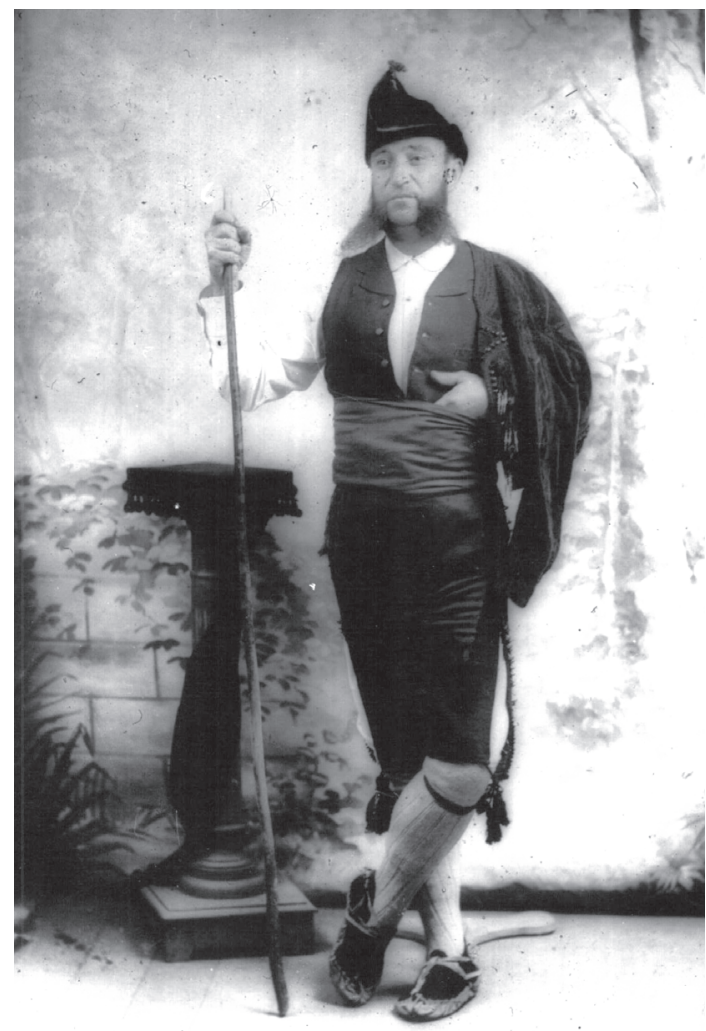

IMAGEN 22.-Representación de una obra de teatro Cándido García. Hacia 1900. A izquierda un gaiteru vestido con un taje de porruanu. Cortesía de Juan Alfonso Fernández García. sica y baile asturiano con el traje del país. De esta temprana relación entre la indumentaria americana y la llanisca se conserva un documento particular. En una copia de una fotografía atribuida a Baltasar Cue y fechada entre 1892 y 1894 registrada en el Archivo de El Oriente de Asturias, se puede apreciar cómo Francisco Álvarez Lavandera "Pancho El Barrileru", un conocido interprete de los bailes tradicionales llaniscos — como el Pericote- viste un traje con la influencia de las chaquetas de estilo militar de las que, con sus remontas ornamentadas y botoneras destacadas, se utilizaron en Cuba en la década de 1880 y que fueron registradas por los fotógrafos de la época. No se ha encontrado información sobre una temprana presencia en la isla caribeña de este popular bailarín, que justificase el uso de este estilo del traje asturiano de hombre en Llanes, ni se conservan ni se han documentado hasta el momento otras imágenes de danzarines o gaiteros vestidos con esta misma chaqueta, pero la estética de la prenda es igual a las lucidas en Cuba diez años antes a la fecha la fotografía.

Será otro fotógrafo llanisco quien dará cuerpo iconográfico al uso de una indumentaria considerada ya como un traje particularizado y entendiéndose que se le puede 
aplicar la denominación específica de porruanu. Se trata del atavío que el retratista Cándido García ponía a disposición de sus clientes en su estudio, pudiendo posar para la cámara con un atuendo del país. No con cualquier traje, sino con uno asociado particularmente con Llanes, caracterizado por sus remontas negras sobre un paño más claro y que con su distribución en mangas, pechera y perneras recuerda a las interpretaciones historiadas de inspiración militar que se documentaron en Cuba primero y después en México, y en las que la chaqueta ya no se lleva terciada al hombro, sino puesta pero con las mangas libres. La imagen en principio más antigua que se conserva de este traje, es la perteneciente a la Fototeca del Muséu del Pueblu d'Asturies, en la que los intervinientes en una obra de teatro se retratan en el estudio del citado fotógrafo Cándido García, con un gaiteru en la margen superior derecha vestido con esta singular indumentaria y fechada hacia 1900.

Datada varios años más tarde y tomada con motivo de la visita de la Infanta Paz de Borbón a Asturias en mayo de 1914, se conserva una fotografía en el Archivo de El Oriente de Asturias, en la que la imagen recuerda las palabras de Cayetano Rubín de Celis, cuando señalaba quién se vestía de porruanu. A la derecha se puede observar a Manolo Rivas, el gaiteru la Portilla, con su indumentaria diferenciada junto a otro mozo vestido de asturiano sin las características remontas del atuendo de porruanu. A la izquierda aparece un hombre vestido con el traje del estudio de Cándido García. Se trata del mismo con el que se retrataron la triada de dos aldeanas y un porruanu fechada en 1917; el mismo, por otra parte, con el que se sacó un recuerdo un mozo en un grupo familiar formando una composición de ambiente folclórico en el estudio del fotógrafo y en cuyo reverso manuscrito se lee «Este le recordando mis vailes sanmiguelinos. Por todos. Mª Galguera 16-8-1921 (sic)».

Independientemente de las distintas hipótesis con respecto al origen de la denominación porruanu, cabe plantearse la tesis de una relación entre las reinterpretaciones del traje asturiano llevadas a cabo en Cuba primeramente, con las pellizas de caballería como referente estético y de prestigio social, y la hecha en México unos años más tarde, circunscrita prácticamente a tenor de las imágenes conservadas, a la fiesta celebrada en la finca de Coapa en 1890. Una forma de entender la indumentaria asturiana que sería introducida en Llanes, en principio y a la espera de nuevos documentos fotográficos, por medio de la familia Rubín de Celis. La intervención de los indianos en la construcción de una indumentaria identitaria en el concejo de Llanes, quedaría entonces asociada con el traje asturiano de hombre, importando desde las colonias el gusto por el ornamento vistoso y llamativo, que fue adoptado poco a poco por bailarines y gaiteros, muchas veces contratados y pagados por los propios indianos para amenizar diferentes festejos, como las romerías locales y otros eventos de carácter privado. En estas primeras imágenes, de nuevo es notable la ausencia de hombres ajenos al espectáculo folclórico vestidos con esta indumentaria. Parece así establecerse una relación paradójica entre los mecenas y patrones que pagan y benefician a quienes amenizan los festejos o participan en ellos vestidos de porruanu -o de asturiano en general- pero que siguiendo la pauta de las clases acomodadas locales no lo utilizan en su tierra de origen, aunque sí lo hagan en los lugares de emigración.

Años más tarde, la reconocida figura de Ramón Sobrino Pérez, "El Nino de Pancar", un destacado bailarín en la interpretación de El Pericote, contribuyó a la difusión y 


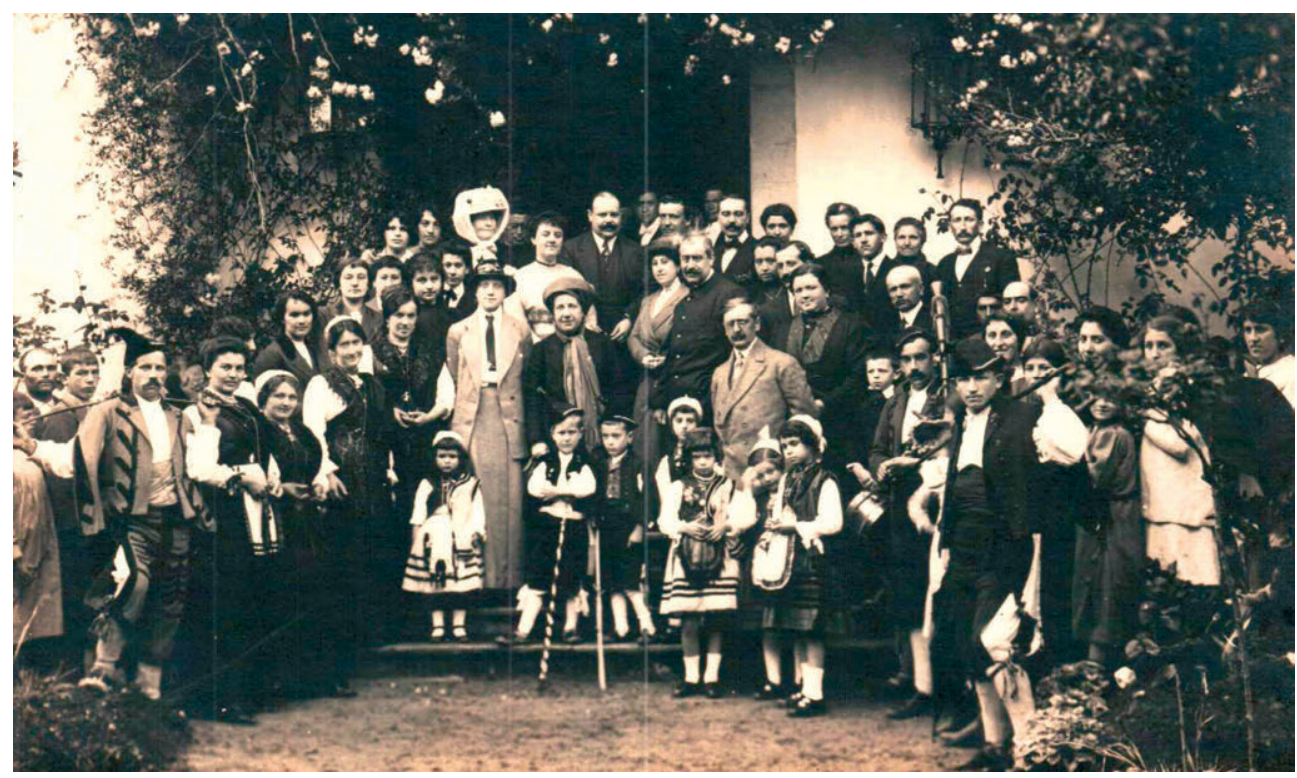

Imagen 23.- Retrato de grupo de estancia de la Infanta Paz de Borbón en Vidiago de Llanes en 1914. Destaca la presencia de tres hombres vestidos de asturianos, dos de ellos con el traje de porruanu con sus remontas. Archivo del semanario El Oriente de Asturias.

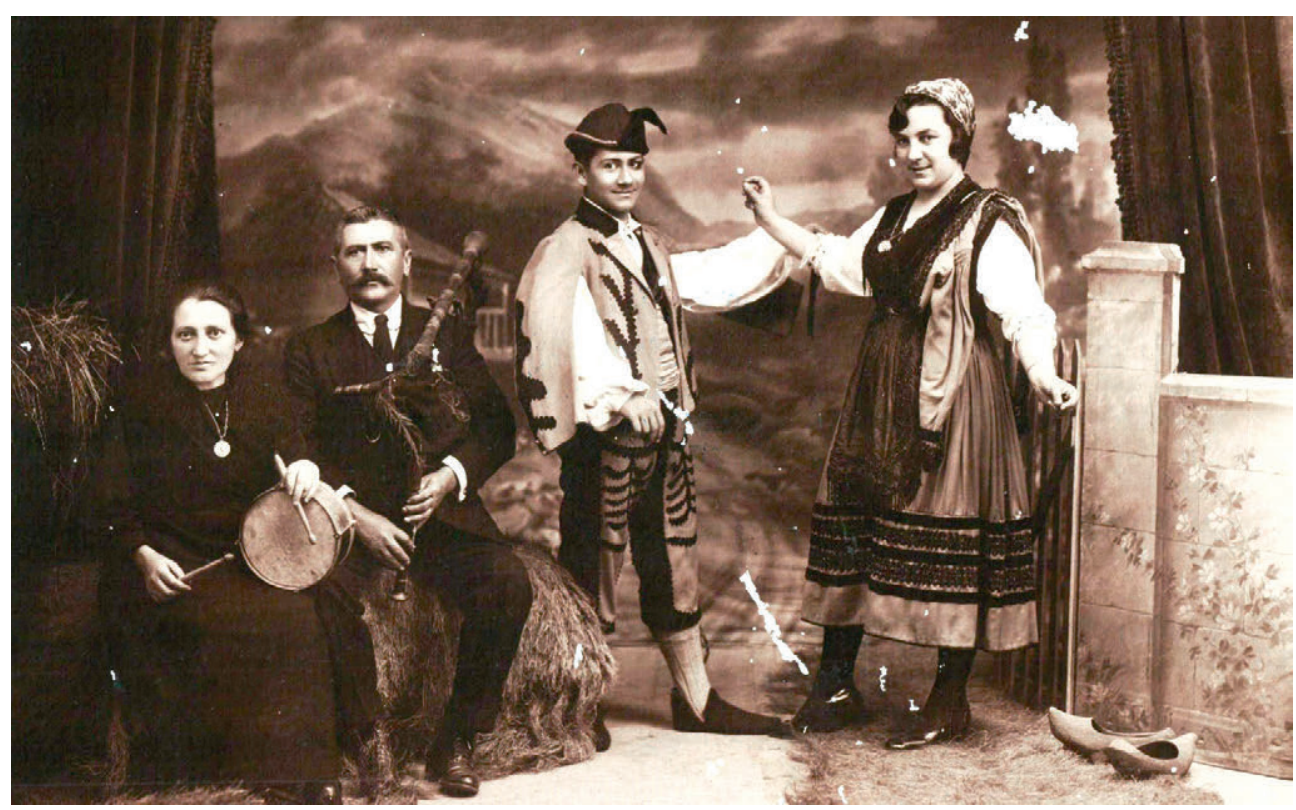

IMAGEN 24.- Retrato representando un ambiente festivo, con una mujer al tambor, un hombre con una gaita y una pareja preparada para bailar, el ataviado con el traje de porruanu perteneciente al estudio del fotógrafo. Cándido García. Reverso manuscrito: "Este le recordando mis vailes sanmiguelinos. Por todos. M. a Galguera 16-8-1921 (sic)». Archivo del semanario El Oriente de Asturias. 
reconocimiento de esta indumentaria; una vez más vinculada a la representación de los bailes populares, tanto como espectáculo para subir a un escenario como parte integrante de la fiesta en general. Se construía así un proceso de aceptación que, a lo largo del siglo XX, terminó por asociar la indumentaria masculina del traje de porruanu en la manifestación festiva per se, formando parte del rito del ofrecimiento del ramu, e independientemente de que se participase en la representación de bailes tradicionales o fuesen simples instrumentistas en el acompañamiento de los mismos.

IMAGEN 25.-Ramón Sobrino «El Nino de Pancar" junto a Ignacio Noriega el gaiteru de San Roque y un tamboriteru sin identificar fotografiados en Covadonga, todos ellos vestidos de porruanos. Tarjeta Postal. Foto Pepe. Ediciones Buj. Llanes. Hacia 1955. Fototeca del Muséu del Pueblu d'Asturies. N. ${ }^{\circ} 38.847$.

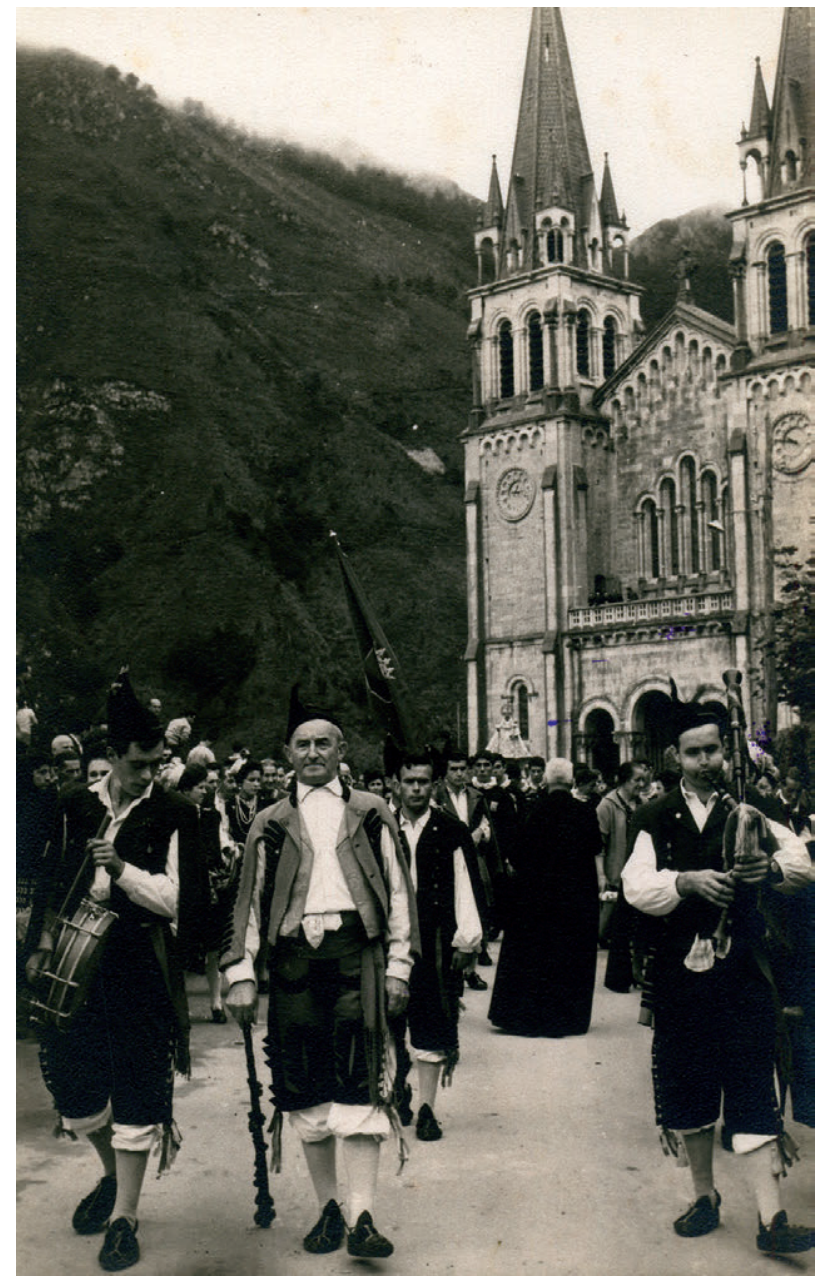




\section{BIBLIOGRAFÍA CITADA}

Aza, Vital. 1896. La Praviana. Comedia en un acto y en prosa. Madrid: Administración Lírico-dramática.

Baer, Alejandro. 2009. La construcción de la memoria. Breve guía para perplejos. Madrid: Trotta.

Bourdieu, Pierre. 2007. El sentido práctico. Buenos Aires: Editores Argentina.

Canella. Fermín. 1900. "De vita et moribus". Revista Asturias: 60-61.

Cerra Bada, Yolanda. 2008. "La ofrenda de ramo, un ritual en las fiestas asturianas". Revista Bedoniana: Anuario de San Antolín y Naves 10: 169-179.

Cerra Bada, Yolanda. 2009. "Aldeanas y porruanos, vestidos para el ritual festivo". Revista Bedoniana: Anuario de San Antolín y Naves 11: 179-205.

Crabiffosse Cuesta, Francisco. 2000. Asturianos en América (1840-1940). Fotografía y Emigración. Xixón: Muséu del Pueblu d'Asturies.

Cue Fernández, Baltasar. 2012. Tipos populares de Llanes. 1885-1990, en Juaco López Álvarez y Francisco Crabiffosse Cuesta (eds.). Gijón: Muséu del Pueblu d'Asturies.

Elías, Norbert. 1994. La teoría del símbolo. Barcelona: Península.

Erice Sevares, Francisco. 2013. "Los asturianos ante la guerra de Cuba (1895-1898)". En Evaristo Martínez-Radío Garrido (ed). Entemu. Aportaciones a cinco siglos de la historia militar de España: 147-234. Gijón: UNED.

Fernande Gutierri, Gausón. 2007. El paxellu asturianu o traxe’l pais. Oviedo: Cajastur.

Flusser Vilem. 1990. Hacia una filosofía de la fotografía. Méjico: Trilla.

Freund. Gisèle. 1983. La fotografía como documento social. Barcelona: Gustavo Gili.

García Canclini, Néstor. 1997. "Culturas híbridas y estrategias comunicacionales". Estudios sobre las culturas contemporáneas. Junio año/vol. III: 109-128.

García Mijares, Manuel. 1990. Apuntes bistóricos, genealógicos y biográficos de Llanes y sus bombres. Llanes: El Oriente de Asturias.

Gelpi y Ferro, Gil. 1872. Álbum Histórico y Fotográfico de la Guerra de Cuba desde su principio hasta el reinado de Amadeo I. La Habana: Imprenta La Antilla.

Lara López, Emilio Luis. 2005. "La fotografía como documento histórico-artístico Antropológico. Una epistemología". Revista de antropología experimental n. ${ }^{\circ}$. Texto10. Universidad de Jaén.

Lisón Arcal, José Carmelo. 2005. "Investigando con fotografía en antropología social". En Maneras de mirar. Lecturas antropológicas de la fotografía. Madrid: CSIC.15-31.

López Álvarez, Juaco. 1993. "Emigración y localismo: sociedades asturianas en La Habana". Astura: Nuevos cartafueyos d'Asturies, N. ${ }^{\circ}$ 9: 53-59.

López Álvarez, Juaco. 2010. "Antonio Machado Álvarez y Asturias. Once cartas inéditas de Machado Álvarez a Fermín Canella Secades. 1880-1884". DEMOFILO Revista de Cultura Tradicional de Andalucía (2. ${ }^{a}$ Época de EL FOLKLORE ANDALUZ). Disponible en: <http://s3.redmeda.com/biblioteca/lopez_2010_machado.pdf>. Fecha de acceso: 24 abr. 2013.

Medina Miranda, Héctor Manuel. 2009. Los charros en España y México. Estereotipos ganaderos y violencia lúdica. Disponible en: <http://gredos.usal.es/jspui/handle/10366/83186>. Fecha de acceso: 20 oct. 2015.

Ortiz García, Carmen. 2012. "Folclore, tipismo y política. Los trajes regionales de la Sección Femenina de Falange". Gazeta de Antropología. Disponible en: <http://hdl.handle.net/10481/22987>. Fecha de acceso: 20 oct. 2015.

Otero Vega. Eugenio, Fonsu Fernández García, y Gausón Fernande Gutierri. 2011. Cancionero de la Gaita asturiana. I Historia y Usos. Xixón: Muséu del Pueblu d'Asturies.

Palacio Valdés, Armando. 1903. La aldea perdida. Disponible en: <http://www.gutenberg.org>. Fecha de acceso: 20 oct. 2015.

Palma Crespo, Antonio David. 2014. "Enrique Facio y el nacimiento de la fotografía de guerra en España". Fotocinema 9: 298-324. Disponible en: <http://www.revistafotocinema.com/index.php?journal= fotocinema\&page $=$ article\&op=view\&path[]=264\&path[]=189>. Fecha de acceso: 21 oct. 2015.

Rada y Delgado, Juan de Dios de la. 1860. Viaje de Sus Majestades y Altezas Reales por castilla León Asturias y Galicia, verificado en el verano de 1858. Madrid: Aguado, Impresor de Cámara de Su Majestad la Reina. 
Santoveña Zapatero, Fe. 2013. Vestidos de asturianos 150 años de fotografía e indumentaria en Asturias. Gijón: Muséu del Pueblu d'Asturies.

Sarmiento Ramírez, Ismael. 1999. "De las fiestas de Covadonga a las jiras de los asturianos en Cuba (1868-1898)". Militaria. Revista de Cultura Militar. 209-244. Disponible en: <https://dialnet.unirioja.es/ descarga/articulo/1455943.pdf>. Fecha de acceso: 20 oct. 2015.

Sontag, Susan. 2005. Sobre la fotografia. Madrid: Alfaguara.

Turner, Víctor W. 1988. El proceso ritual. Madrid: Taurus.

Velasco Maillo, Honorio Manuel. 1990. "El folclore y sus paradojas". Reis. Revista Española de Investigaciones sociológicas 9: 123-144.

Fecha de recepción: 25 de octubre de 2015.

Fecha de aprobación: 20 de mayo de 2016. 